\title{
Performance Analysis of Techniques Used for Determining Land Mines
}

\author{
Yavuz Ege ${ }^{*}$, Adnan Kakilli², Osman Kılıç², Hüseyin Çalık³ ${ }^{3}$ Hakan Çıtak4, Sedat Nazlıbilek \\ Osman Kalender6 \\ ${ }^{1}$ Department of Physics, Necatibey Faculty of Education, Balikesir University, Balikesir, Turkey \\ ${ }^{2}$ Electrical Education Department, Technical Education Faculty, Marmara University, İstanbul, Turkey \\ ${ }^{3}$ Technical Sciences Vocational High School, İstanbul University, İstanbul, Turkey \\ ${ }^{4}$ Balikesir Vocational High School, Balikesir University, Balikesir, Turkey \\ ${ }^{5}$ Department of Mechatronics Engineering, Faculty of Engineering, Atilim University, Ankara, Turkey \\ ${ }^{6}$ Department of Electrical-Electronics Engineering, Faculty of Engineering, Orhangazi University, Bursa, Turkey \\ Email: *yavuzege@gmail.com
}

Received 29 May 2014; revised 21 June 2014; accepted 15 July 2014

Copyright (C) 2014 by authors and Scientific Research Publishing Inc.

This work is licensed under the Creative Commons Attribution International License (CC BY).

http://creativecommons.org/licenses/by/4.0/

(c) (7) Open Access

\section{Abstract}

Today, remote sensing is used for different methods and different purposes. In all of the detection methods, some considerations such as low energy consumption, low cost, insensitivity to environmental changes, high accuracy, high reliability and robustness become important. Taking into account these facts, remote sensing methods are used in applications such as geological and archeological research, engineering areas, health services, preserving and controlling natural life, determination of underground sources, controlling air, sea and road traffic, military applications, etc. The method to be used is based on the object type to be detected, material to be made, and location to be found. The remote sensing methods from the past up to today can be listed as acoustic and seismic, ground penetration radar (GPR) detection, electromagnetic induction, infrared (IR) imaging, neutron quadrupole resonance (NQR), thermal neutron activation (TNA), neutron back scattering, $\mathrm{X}$-ray back scattering, and magnetic anomaly detection. In these methods, detected raw images have to be processed, filtered and enhanced. In order to achieve these operations, some algorithms are needed to be developed. In this study, the methods used in detecting land mines remotely and their performance analysis have been given. In this way, the last situation on the advantages and disadvantages of methods used, application areas and detection accuracies are determined. Furthermore, the algorithms such as transmission line matrix (TLM), finite difference time-domain (FDTD), the method of moment (MoM), split step parabolic equation (SSPE) and image processing and intelligent algorithms are presented in detail.

${ }^{*}$ Corresponding author.

How to cite this paper: Ege, Y., Kakilli, A., Kılıç, O., Çalık, H., Çıtak, H., Nazlıbilek, S. and Kalender, O. (2014) Performance Analysis of Techniques Used for Determining Land Mines. International Journal of Geosciences, 5, 1163-1189.

http://dx.doi.org/10.4236/ijg.2014.510098 


\section{Keywords}

\section{Remote Sensing, Land Mine, Detection Performance, Algorithm}

\section{Introduction}

Remote sensing methods used up to today can be listed as acoustic and seismic, ground penetration radar (GPR) detection, electromagnetic induction, infrared (IR) imaging, nuclear quadrupole resonance (NQR), thermal neutron activation (TNA), neutron backscattering, X-ray backscattering and magnetic anomaly. In recent studies on the remote sensing, instead of finding a new method, some of the issues such as low power consumption, low cost, immunity to environmental changes, high sensitivity, high reliability and robustness are considered. Therefore, it is concentrated on the studies of increasing the performance of sensors used in sensing methods and assessing the results from multiple methods together. Method(s) selected depend(s) on the type of object, material used, and the location where it is found. Today, remote sensing methods are used effectively in the areas such as geological and archeological researches, engineering fields, health services, control and protection of natural life, determination of underground sources, determination of underground sources, air, sea and land traffic control, and military applications. In military applications, these methods are normally used for the detection of buried land mines.

Land mines can be divided into two types as anti-personnel (AP) and anti-tank (AT) mines. Anti-personnel mines are used to defend strategical locations or points such as important fields or bridges, to prevent passages of military or civilian people across boundaries, while anti-tank mines are used to obstruct vehicle traffic. Estimated mine depth, date of burial and the type of mine determine the technology selection for detection. Mine detection and clearing works are highly serious problems today all over the world. To buy and use these hidden killers are very cheap but to detect and remove them are very expensive. Buying a mine costs about $\$ 3$ but removing it costs about $\$ 1000$ [1]. There are about 100 million unexploded mines at least in 80 countries over the world [1]. This continuously growing threat affects not only the military but also civilian people. Since the life cycle of a mine is very long, the victims are not always the target group, instead innocent people especially the children are the victims most probably [2] [3]. Around 26,000 people, of which the most are civilians, have been killed or injured by explosion of mines [1]. Existences of buried mines are a threat to living creatures, and also become a huge obstacle in front of economical growth, development and wealth of people. For example, use of buried mines under the terrains prevents them to be used for agricultural purposes and caused loss of fertile areas. Mine detection is a complicated problem that it is very difficult to solve by today's techniques. Three difficulties can be listed in this subject:

- Difficulty in the classification because of the existence of about 700 different types of mines showing large variations;

- Difficulty in the determination of mines because of the materials used that are mostly composed of plastic products and less metals;

- Difficulty in the elimination of false alarms due to environmental factors at the mine fields preventing detection and identification.

The fundamental issues for mine detection technologies are low false alarm ratio, high identification ratio of actual mine and high detection rate. In order to satisfy all these factors, different algorithms can be used. The procedural mechanisms of almost all of the algorithms can be divided into four phases such as preprocessing, feature extraction, credit assignment and decision making. The requirements of the algorithms are those of computational efficiency and memory capacity. In this study, the methods used up to today and their performances for remote sensing of land mines are analysed. Furthermore, the algorithms used for mine detection are presented in this paper.

\section{Land Mine Detection Technologies}

\subsection{Acoustic Seismic Reflection Method}

Acoustic seismic approach is based on the principle that the sound waves given by a source under the ground are reflected from the boundaries of structures and objects themselves. In this method, reflected sound waves are 
collected by sensors after the excitation of the soil by acoustic sound with a frequency less than $1 \mathrm{kHz}$ and analysed for resulting anomalies at the round of times of the waves.

Vibration of the soil is provided by the acoustic waves carried on the air and seismic waves carried in the soil. In this case, different oscillations occur based on the different underground structures and movement of soil. Thus, the characteristic features of the ground can be determined by recording the signals received in $\mu \mathrm{V}$ levels by the sensors. In this method, non-linear distorsion is important and distinctive information for mine detection. For this reason, this method can be used for high detection probability and low false alarm ratio applications. However, it has some disadvantages that it gives false alarms in wet and high conductive areas and in the case where the mines are close to the surface [4], it is slow compared to the other methods (2 - $\left.15 \mathrm{~min} / \mathrm{m}^{2}\right)$ [2], it requires a lot of computational steps in software [5], it is unsuccessful when the mines buried in deeper levels [2] [6], it is sensitive to acoustic vibrations and noise, it has more expensive equipment than the other methods, etc.

In this study, the works on the buried mine detection using acoustic seismic method are examined and performance parameters are determined [4] [6] [7]-[9]. The principle of acoustic seismic method for mine detection is given in Figure 1. The following variables are selected for performance criteria parameters for each work that is examined: soil type, material tested, test height, working rate and frequency, findings under these conditions. Table 1 gives the comparison of performance parameters for these works.

As seen from Table 1, the application frequency is held about at $450 \mathrm{~Hz}$ and the plastic metal covered land mines can be detected in soil or sand at a height of $5 \mathrm{~cm}$. In case the frequency and wave speed of the sound wave are increased, the maximum height at sea level is determined as $55 \mathrm{~m}$, however at lower frequencies the maximum performance is determined as $5-10 \mathrm{~cm}$ below the sea level.

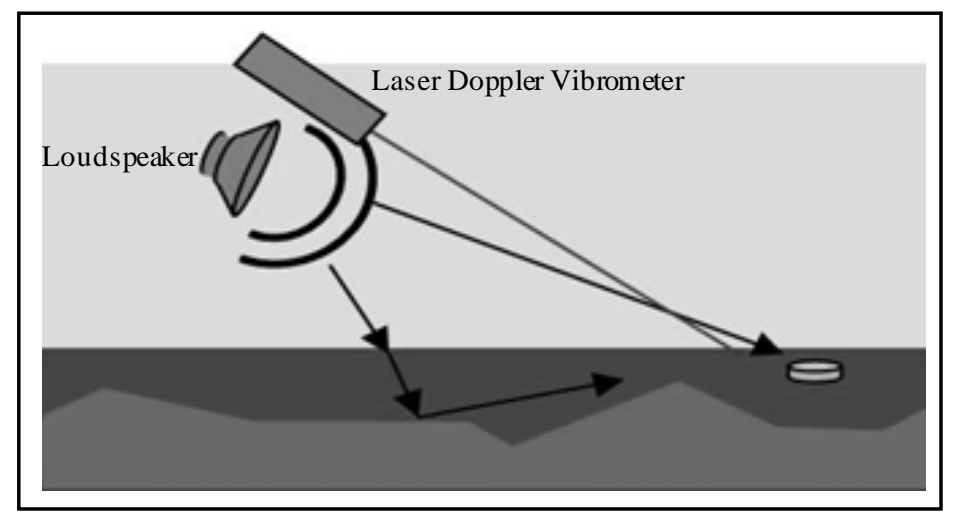

Figure 1. Principle of acoustic-seismic method.

Table 1. Performance analysis of acoustic-seismic method for land mine detection.

\begin{tabular}{|c|c|c|c|c|c|}
\hline Soil type & Material tested & Test height & $\begin{array}{l}\text { Operation speed or } \\
\text { frequency }\end{array}$ & $\begin{array}{c}\text { Operation } \\
\text { performance }\end{array}$ & References \\
\hline Soil & Land mine & $40 \mathrm{~cm}$ & $\begin{array}{c}100-1000 \mathrm{~Hz} \\
80-140 \mathrm{~m} / \mathrm{s}\end{array}$ & $0.5-2 \mathrm{~cm}$ & [4] \\
\hline Dry sand & $\begin{array}{c}\varnothing 8 \mathrm{~cm} \text { plastic mine } \\
30 \times 30 \times 10 \mathrm{~cm} \text { anti tank } \\
\text { mine }\end{array}$ & $\begin{array}{l}2 \mathrm{~cm} \\
5 \mathrm{~cm}\end{array}$ & $430 \mathrm{~Hz}$ & $\begin{array}{l}2 \mathrm{~cm} \\
5 \mathrm{~cm}\end{array}$ & {$[6]$} \\
\hline Dry sand & $\begin{array}{l}\text { TS-50 anti personnel } \\
\text { mine } \\
\varnothing 9 \mathrm{~cm} \mathrm{~h}=4.6 \mathrm{~cm} \\
\rho=1400 \mathrm{~kg} / \mathrm{m}^{3}\end{array}$ & $\begin{array}{l}\text { Source height } 70 \mathrm{~cm} \\
\text { Sensor height ground level } \\
\text { Depth of mine } 2 \mathrm{~cm}\end{array}$ & $\begin{array}{c}\text { Speed of transmitted } \\
\text { wave } 50 \mathrm{~m} / \mathrm{s} \\
450 \mathrm{~Hz}\end{array}$ & $\begin{array}{l}\text { Tested only for } \\
\text { Sadece } 2 \mathrm{~cm}\end{array}$ & [7] \\
\hline Dry sand & $\begin{array}{l}\text { Plastic mine } \rho=1200 \\
\mathrm{~kg} / \mathrm{m}^{3}\end{array}$ & $\begin{array}{l}\text { Source height } 2 \mathrm{~cm} \\
\text { Source at ground level }\end{array}$ & $450 \mathrm{~Hz}$ & $\begin{array}{l}\text { Underground } \\
\text { (not specified) }\end{array}$ & {$[8]$} \\
\hline Water & AN/SQQ-32 sea mine & Below sea level & $600 \mathrm{~Hz}-100 \mathrm{KHz}$ & $\begin{array}{l}\text { Wave speed } 1520 \mathrm{~m} / \mathrm{s} \text {, } \\
35 \mathrm{~m} \\
\text { Wave speed } 1510.5 \mathrm{~m} / \mathrm{s} \text {, } \\
55 \mathrm{~m}\end{array}$ & [9] \\
\hline
\end{tabular}




\subsection{Ground Penetrating Radar (GPR) Method}

Ground penetrating radar (GPR) method is based on determining objects buried underground using radio waves at different frequencies $(1-1000 \mathrm{MHz})$. In this technique, electrical characteristics of the objects under the ground are observed by means of electrical and magnetic changes. It is essential that the radio waves sent by a transmitter antenna have to be reflected from the object under the ground. These reflected waves are recorded in the receiver. Since the objects have natural resonance frequencies that are different from the environment where they are found, the waves reflected from the surface of the object and the waves reflected from the environment where the object is found will show a difference depending upon the amount of absorption of the radio waves sent. But, the bandwidth of the radar signals shall be adjusted so that the natural resonance frequency of the object could be extracted [10]. Detection of reflection is not always easy because of the side effects. Variable parameters such as inhomogeneity of soil, humidity, existence of other objects, surface roughness, etc, can disturb and cover the reflections received [11] [12]. Furthermore, small cavities between the soil and object, roots of plants, the differences between soil and large stones or rocks may cause misleading reflections. This increases the false alarms that are the most important handicaps for this method [1]. During trying to detect a mine in wet sand by the GPR method, another mine that is buried in a dry sand in the vicinity of the first one cannot be detected [13]. Detecting signals from potentially varying environments and correctly interpreting them are very important. Therefore, GPR problems bring a big load to the computer that has to implement the mathematical models by appropriate algorithms and use filtering. The most important issue in GPR systems is to choose the appropriate frequency of radio wave that is sent to ground. When we work with high frequencies, we can obtain results with high resolution. However, increasing the antenna frequency may decrease the depth of study. If the required depth is $d$ and the dielectric coefficient of the environment is $\varepsilon$, the appropriate frequency can be found by the expression in Equation (1) [14].

$$
f=\frac{150}{d \times \sqrt{\varepsilon}}
$$

Normally, the antenna with the lowest frequency can give an opportunity of studying deepest ground. In this case, a preference between the depth of study and the quality of the image has to be done. The tradeoff between the depth and the quality of the image depends on the factors such as environmental conditions, soil type and the position of the object.

3-D GPR problem has four main components. These are the ground, the air, the radar unit and the object. The ground-air interface is in the z-plane and the radar unit collects the data at a fixed altitude. When the position of the radar unit is changed linearly through $\mathrm{x}$-axis and the measurements are repeated and the resulting reflections are put together, a 2-D image dependent on space and time can be obtained.

In our study, works on the detection of land mines using ground penetration radar (GPR) are investigated and again the following variables are selected for performance criteria parameters for each work that is examined: soil type, material tested, test height, working rate and frequency, findings under these conditions [1] [11] [12] [15]-[35]. Figure 2 gives the principle of the GPR method for mine detection.

As seen from Table 2, the application frequency is around 1 - $5 \mathrm{GHz}$, plastic and metal covered land mines can be detected at a maximum height of $20 \mathrm{~cm}$ in clay soil or wet soil. It is observed that increasing the radio frequency may also increased the dept of detection.

\subsection{Electromagnetic Induction (EMI) Method}

When a time varying magnetic field is established at the environment where a conductive object is found, an electric field is inducted on the conductive object and this field creates a flow of charge inside the object. The inducted current on the object because of the charge flow produces a secondary magnetic field. When the secondary magnetic field produced is investigated over a wide range of the band ( $30 \mathrm{~Hz}-24 \mathrm{kHz}$ ), a signal specific to and defining of the object has been obtained. The frequency to be selected for the object to be detected depends on the depth $d$ (inch), relative magnetic permeability $\mu_{r}$ of the object and electrical resistance $R$ (ohm) of the object as given in Equation (2) [37].

$$
f=2500 \times \frac{R}{\mu_{r} \times d^{2}}[\mathrm{~Hz}]
$$


Table 2. Performanceanalysis of land mine detectionby GPR.

\begin{tabular}{|c|c|c|c|c|c|}
\hline Soil type & Materials tested & Test height & $\begin{array}{l}\text { Operational speed or } \\
\text { frequency }\end{array}$ & Performance of work & References \\
\hline Soil & $\begin{array}{l}\text { VS50 Anti personnel } \\
\text { mine }\end{array}$ & $\begin{array}{l}\text { Source on the ground } \\
\text { surface }\end{array}$ & $400 \mathrm{MHz}$ & $10 \mathrm{~cm}$ & [11] \\
\hline Soil & $\begin{array}{c}\text { Anti tank mine } \\
\text { (containing both high } \\
\text { and low metal content) }\end{array}$ & $\begin{array}{l}\text { Height of the source } \\
\text { is } 5 \mathrm{~cm}\end{array}$ & $200 \mathrm{MHz}-7 \mathrm{GHz}$ & $\begin{array}{c}2.5-15.2 \mathrm{~cm} \\
\text { (success \%87.5) }\end{array}$ & [1] \\
\hline Soil & Mine resembling targets & $\begin{array}{l}\text { Source is on the } \\
\text { ground surface }\end{array}$ & $300 \mathrm{MHz}$ & $\begin{array}{c}5 \mathrm{~cm} \text { (false alarm ratio in } \\
\text { an area with a radius of } \\
45 \mathrm{~cm} \text { is } 6.9 \% \text { ) }\end{array}$ & [15] \\
\hline $\begin{array}{l}\text { Soil with stone and } \\
\text { clay covered by } \\
\text { grass }\end{array}$ & $\begin{array}{c}\text { Anti tank mine } \\
\varnothing 20 \mathrm{~cm} \mathrm{~h}=310 \mathrm{~cm} \\
\text { Anti personnel } \\
\text { (metallic) } \\
\varnothing 8 \mathrm{~cm} \mathrm{~h}=15 \mathrm{~cm}\end{array}$ & $\begin{array}{l}\text { Source on the ground } \\
\text { surface }\end{array}$ & $0.7-2.7 \mathrm{GHz}$ & $20 \mathrm{~cm}$ & [17] \\
\hline Dry sand & $\begin{array}{l}\varnothing 12 \mathrm{~cm} 450 \text { Hp power } \\
\text { piston, } \\
1.25 \text { literplastic water } \\
\text { filled cup }\end{array}$ & $1.2 \mathrm{~m}$ & $1-3 \mathrm{GHz}$ & $\begin{array}{c}\text { Image taken } \\
2 \mathrm{~cm} \\
\text { No image could be taken }\end{array}$ & [18] \\
\hline Soil $\left(\varepsilon_{r}=6\right)$ & $\begin{array}{l}\text { M14 plastic anti } \\
\text { personnel mine }\end{array}$ & $0.5-2 \mathrm{~cm}$ & $800-3.5 \mathrm{MHz}$ & $15 \mathrm{~cm}$ & [19] \\
\hline Soil & $\begin{array}{l}\text { Metallic and plastic anti } \\
\text { personnel mine }\end{array}$ & $\begin{array}{l}15 \mathrm{~cm} \text { above the } \\
\text { ground }\end{array}$ & $1300 \mathrm{MHz}$ & $\begin{array}{l}\text { Several } \mathrm{cm} \text { in a depth } \\
\text { from the surface }\end{array}$ & [20] \\
\hline $\begin{array}{l}\text { Dry, wet and } \\
\text { watery soil }\end{array}$ & $\begin{array}{l}\text { TS-50 and VS-50 } \\
\varnothing 8 \mathrm{~cm} \mathrm{~h}=3.2 \mathrm{~cm}\end{array}$ & $\begin{array}{l}\text { Source on the ground } \\
\text { surface }\end{array}$ & $4 \mathrm{GHz}$ & $2 \mathrm{~cm}$ & [21] \\
\hline Clay soil $\left(\varepsilon_{r}=8\right)$ & $\begin{array}{l}\text { TS-50 plastic } \\
\text { anti personnel mine }\end{array}$ & $\begin{array}{l}\text { Very close to the } \\
\text { surface }\end{array}$ & $3 \mathrm{GHz}$ & $2 \mathrm{~cm}$ & [22] \\
\hline Clay soil $\left(\varepsilon_{r}=6.2\right)$ & $\begin{array}{l}\text { Plastic anti personnel } \\
\text { mine }\end{array}$ & $\begin{array}{l}28 \mathrm{~cm} \text { above the } \\
\text { ground }\end{array}$ & $1-3 \mathrm{GHz}$ & $8.5 \mathrm{~cm}$ & [23] \\
\hline Sand & $\begin{array}{l}\text { Anti personnel mine, } \\
\text { stone, brick and metallic } \\
\text { sphere }\end{array}$ & $\begin{array}{l}\text { Source is at the } \\
\text { surface }\end{array}$ & $1 \mathrm{GHz}$ & $1.3,5,10 \mathrm{~cm}$ & [24] \\
\hline Sand & $\begin{array}{c}\text { Metal cylindir, } \\
\text { Water filled plastic, } \\
\text { rubber, metallic sphere } \\
\varnothing 5 \mathrm{~cm} \mathrm{~h}=1 \mathrm{~cm}\end{array}$ & $\begin{array}{l}\text { Very close to the } \\
\text { surface }\end{array}$ & $3 \mathrm{MHz}-2.4 \mathrm{GHz}$ & $2 \mathrm{~cm}$ & [25] \\
\hline Soil & $\begin{array}{c}\text { Anti personnel mine } \\
\varnothing 8 \mathrm{~cm}\end{array}$ & $\begin{array}{l}\text { Very close to the } \\
\text { surface }\end{array}$ & $1 \mathrm{GHz}$ & $15 \mathrm{~cm}$ & [12] \\
\hline Sand $\left(\varepsilon_{r}=2.5\right)$ & $\begin{array}{c}\text { Metallic sphere, } \\
\text { aluminium folio covered } \\
\text { sphere } \varnothing 7.5 \mathrm{~cm}\end{array}$ & $\begin{array}{l}11.5 \mathrm{~cm} \text { above the } \\
\text { ground }\end{array}$ & $100 \mathrm{MHz}-5 \mathrm{GHz}$ & $5 \mathrm{~cm}$ & [27] \\
\hline Sand, loam & $\begin{array}{c}\text { TNT and rock wit a } \\
\text { shape of round, ellipsoid } \\
\text { and rectangle }\end{array}$ & $\begin{array}{l}2.5 \mathrm{~cm} \text { above the } \\
\text { ground }\end{array}$ & $500 \mathrm{MHz}-5 \mathrm{GHz}$ & $2.5-5-10 \mathrm{~cm}$ & [28] \\
\hline Sand & PMN2 land mine & $\begin{array}{l}12 \mathrm{~cm} \text { above the } \\
\text { ground }\end{array}$ & $0.5-5 \mathrm{GHz}$ & $5 \mathrm{~cm}$ & [29] \\
\hline $\begin{array}{l}\text { Natural stone chip, } \\
\text { sinter, sand, soil }\end{array}$ & Steel sphere $\varnothing 5 \mathrm{~cm}$ & $\begin{array}{l}10 \mathrm{~cm} \text { above the } \\
\text { ground }\end{array}$ & $0.5 \mathrm{MHz}-6 \mathrm{GHz}$ & $10-15.5 \mathrm{~cm}$ & [30] \\
\hline $\begin{array}{l}\text { Clay soil } \\
\left(\varepsilon_{r}=3.5\right)\end{array}$ & $\begin{array}{l}\text { TS-50 anti personnel } \\
\text { mine }\end{array}$ & $\begin{array}{l}\text { Very close to the } \\
\text { surface }\end{array}$ & $1-5 \mathrm{GHz}$ & $2.5 \mathrm{~cm}$ & [31] \\
\hline $\begin{array}{l}\text { Soil, dry sand } \\
\text { containing water }\end{array}$ & $\begin{array}{l}\text { NR26 anti tank mine, } \\
\text { PMN anti personnel } \\
\text { mine }\end{array}$ & $4 \mathrm{~m}$ above the ground & $1 \mathrm{GHz}$ & $20 \mathrm{~cm}$ & [34] \\
\hline Soil & $\begin{array}{l}\text { Anti personnel mine } \\
\text { (high and low metal) } \\
\text { Anti tank mine (high } \\
\text { and low metal content) }\end{array}$ & Close to the surface & $0.2-7 \mathrm{GHz}$ & $2.5-5-7.6-10-12.7 \mathrm{~cm}$ & [35] [36] \\
\hline
\end{tabular}


The detectors used for measurements with the electromagnetic induction method are

- Image detection induction coils,

- Magnetic detectors,

- Conductivity meters both in time domain and frequency domain.

In general, the depth range is satisfactory in detecting an object but it is very difficult to identify or distinguish the objects with low metallic content [38]. For that reason, the number of false alarms is greater than the number of actual targets [38] [39]. This high ratio of false alarm may both decrease the detection rate of the mines and it gives rise to an expensive and dangerous situation [2].

In our study, electromagnetic induction (EMI) method is investigated for buried land mine detection and again the following variables are selected for performance criteria parameters for each work that is examined: soil type, material tested, test height, working rate and frequency, findings under these conditions [1] [11] [12] [15]-[35]. Figure 3 gives the principle of the EMI method for mine detection. Table 2 gives the comparison of performance parameters on the works of detecting land mines.

As seenfrom Table 3 that the secondary magnetic field occured by metal covered mines in clay soil and sand areas is examined at the frequency range of $300 \mathrm{~Hz}-2 \mathrm{GHz}$ and it is found that the mines of this type can be detected at a maximum of $10 \mathrm{~cm}$. It is observed that the magnetic permeability and electrical resistance of the cover affect the bandwidth and detection depth.

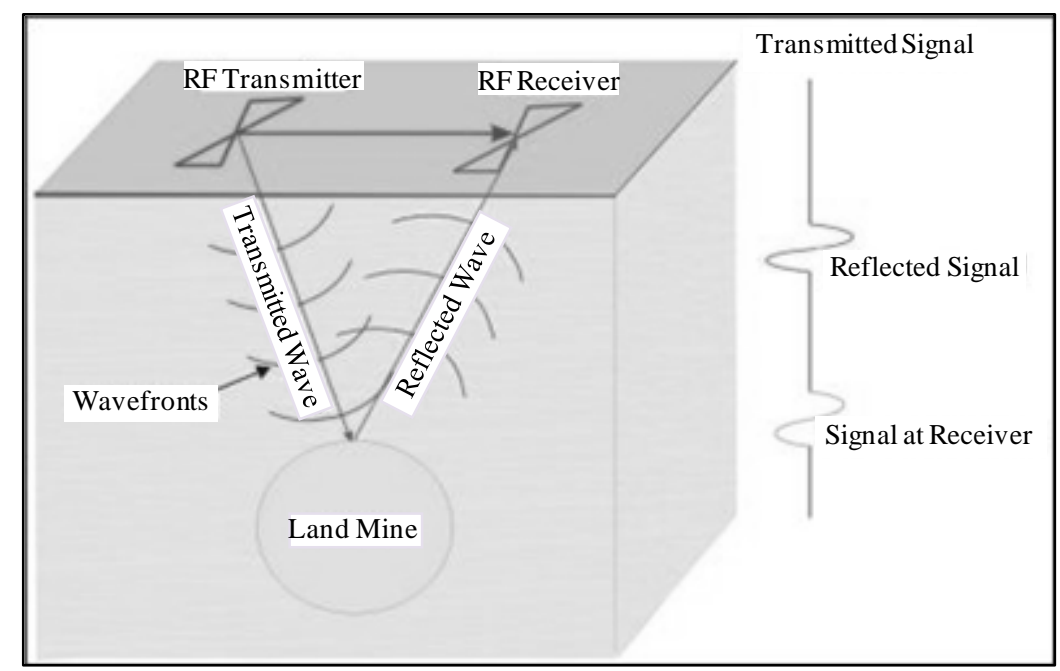

Figure 2. Principle of mine detectionburied mines by GPR.

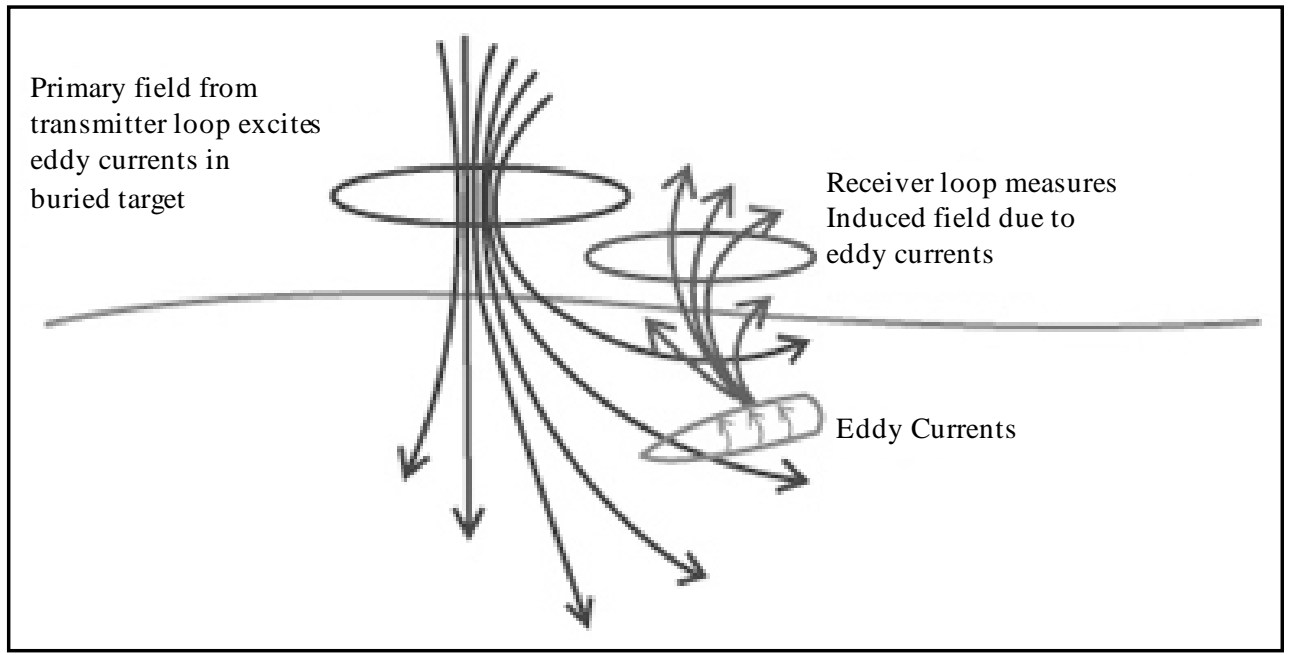

Figure 3. Principle of detecting buried mines by the EMI. 
Table 3. Performance analysis for land mine detection by electromagnetic induction (EMI).

\begin{tabular}{|c|c|c|c|c|c|}
\hline Type of soil & Materials tested & Height of test & $\begin{array}{l}\text { Operating speed } \\
\text { or frequency }\end{array}$ & Performance & Reference \\
\hline Clay and air & $\begin{array}{l}\text { Valmarave VS50 anti } \\
\text { personnel mine }\end{array}$ & $\begin{array}{l}17-19-20-21-23 \mathrm{~cm} \\
\text { above the ground }\end{array}$ & $3990-23,970 \mathrm{~Hz}$ & $\begin{array}{l}\text { On the surface, just under } \\
\text { the ground }\end{array}$ & {$[40][42]$} \\
\hline Sand & $\begin{array}{l}\text { TS-50 and MAI-75 } \\
\text { anti personnel mine }\end{array}$ & $\begin{array}{l}\text { Several } \mathrm{cm} \text { above } \\
\text { the ground }\end{array}$ & $300 \mathrm{~Hz}-90 \mathrm{KHz}$ & $5 \mathrm{~cm}$ & [39] [41] \\
\hline Sand & $\begin{array}{l}\text { Anti personnel mine } \\
\text { (high and low metal } \\
\text { content) } \\
\text { Anti tank mine (high } \\
\text { and low metal } \\
\text { content) }\end{array}$ & $\begin{array}{l}\text { Just above the } \\
\text { ground }\end{array}$ & $330 \mathrm{~Hz}-90.03 \mathrm{KHz}$ & $\begin{array}{c}0-7 \mathrm{~cm} \\
2.5-12.5 \mathrm{~cm}\end{array}$ & [43]-[45] \\
\hline Sand & $\begin{array}{l}\text { Bakalit PT Mi-Ba III } \\
\text { anti tank mine }\end{array}$ & $\begin{array}{l}\text { Just above the } \\
\text { ground }\end{array}$ & $1-2 \mathrm{GHz}$ & $10 \mathrm{~cm}$ & {$[46]$} \\
\hline
\end{tabular}

\subsection{Infrared Imaging Method (IR)}

All of the hot objects emit infrared radiation. This method is based on the determination of infrared radiations at different wavelengths because of the heat difference between the object and the environment. The infrared radiations from the object and the environment can be detected by thermal sensors which are sensitive to heat and visualized as a colored images.

Infrared imaging technique can be used in different applications such as in the control of electrical process equipment, in medical devices, in defence and indoor identifications. It has to be noted that the success of infrared techniques is related to the conditions of operation environment and surface heat changes [47] [48]. In experiments, it was observed that because of roughness of surface, uneven sunshine, continuous change in environmental conditions and difference in oscilation powers of objects, it is difficult to obtain accurate temperature measurements and depending on it interpretation of images correctly [3] [48].

In areas where the type of soil is non-homogeneous and having vegetations formed in time the performance and the depth are not enough [46]. In this technique, it is believed that because of the frequency of the infrared wave used during determining buried objects, it cannot pass the surface of the soil and therefore for detecting buried objects by this technology can only be achieved at special conditions and short time intervals [46] [47].

In our study, infrared imaging (IR) method is investigated for buried land mine detection and again the following variables are selected for performance criteria parameters for each work that is examined: soil type, material tested, test height, working rate and frequency, findings under these conditions [3] [46]-[48] [49]-[52]. Figure 4 gives the principle of the IR method for mine detection. Table 4 gives the comparison of performance parameters on the works of detecting land mines

As seen from Table 4 that the infrared wave frequency is held at a bandwidth of $3 \mathrm{MHz}-140 \mathrm{GHz}$. Plastic and metal covered land mines in sandy soil can be detected at maximum $20 \mathrm{~cm}$. They can be detected in a soil with grass at about $5 \mathrm{~mm}$. If the operating badwidth is increased, then the detection height increases. Some layers such as grass covering the soil may decrease the detection depth.

\subsection{Nuclear Method}

In this method, existence of explosives such as nitrogen based RDX, HMX, PETN and also nitrogen-hydrogen based TNT (Figure 5), but not the outer covers of mines is tried to determine.

\subsubsection{Nuclear Quadrupole Resonance (NQR) Method}

Nuclear quadrupole resonance is a special radio frequency (RF) technique based on detecting nitrogen isotope $\left({ }^{14} \mathrm{~N}\right)$ found in the structure of many explosives and drugs.

Observed NQR frequencies are obtained with the interaction between the electrical quadrupole of the nucleus and electrical field changes formed from outside around the nucleus. The NQR sign that the nitrogen based explosives such as TNT, HMX, RDX and PETN create can be used to detect and identify the amount of explosive and estimate the depth. 


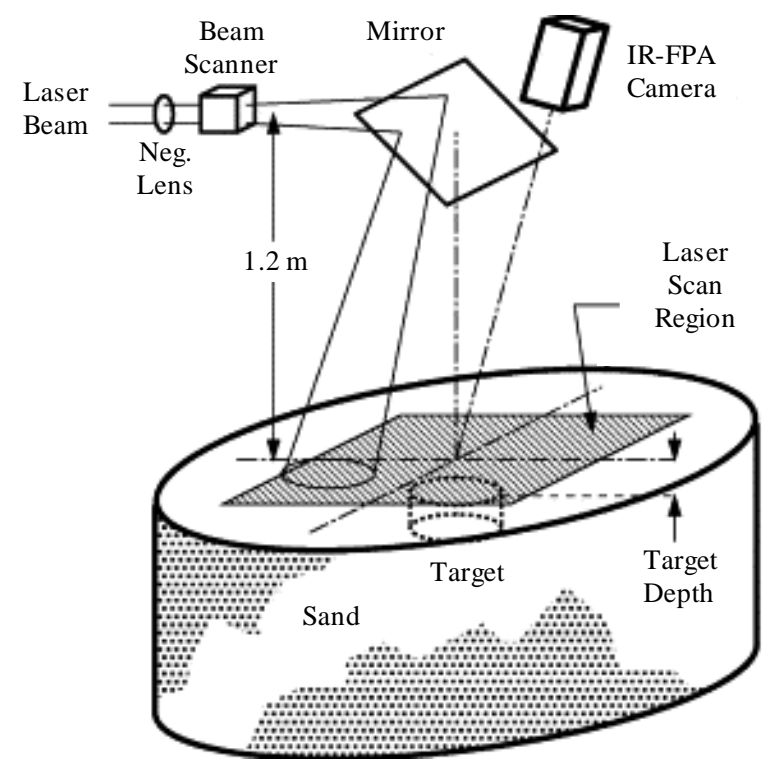

Figure 4. Principle of mine detection by infrared method.<smiles>[R]O[N+](=O)[N+]1CN([N+](=O)[O-])CN([N+](=O)[O-])C1</smiles><smiles>[M]O[N+]([O-])N1CN([N+](=O)[O-])CN([N+](=O)[O-])CN([N+](=O)[O-])C1</smiles><smiles>O=[N+]([O-])OCC(CO[N+](=O)[O-])(CO[N+](=O)[O-])CO[N+](=O)[O-]</smiles><smiles>Cc1c([N+](=O)[O-])cc([N+](=O)[O-])cc1[N+](=O)[O-]</smiles>

Figure 5. Molecular structure of nitrogen and nitrogen-hydrogen based explosives.

Table 4. Performance analysis of land mine detection by infrared imaging method.

\begin{tabular}{|c|c|c|c|c|c|}
\hline Soil type & Materials tested & Height of test & Speed or frequency & $\begin{array}{c}\text { Performance of } \\
\text { study }\end{array}$ & Reference \\
\hline Sand & $\begin{array}{c}\text { Cola can, } \\
\text { Bakalit PT Mi-Ba III anti } \\
\text { tank mine } \\
\text { PPM-2 anti personnel mine }\end{array}$ & $\begin{array}{l}\text { Just above the } \\
\text { ground }\end{array}$ & $\begin{array}{l}\text { Wave length } \\
3-5 \mu \mathrm{m} \\
8-12 \mu \mathrm{m}\end{array}$ & $\begin{array}{c}10 \mathrm{~cm} \\
10 \mathrm{~cm} \\
\text { Just under the } \\
\text { surface (best image) }\end{array}$ & [46] \\
\hline $\begin{array}{l}\text { Sand and } \\
\text { surface with } \\
\text { vegetation }\end{array}$ & Anti personnel plastic mine & Above the ground & $8-12 \mu \mathrm{m}$ & $1 \mathrm{~cm}$ & [47] \\
\hline $\begin{array}{l}\text { Sand, grass and } \\
\text { leaves and } \\
\text { asphalt surface }\end{array}$ & $\begin{array}{l}\text { Plastic anti personnel } \\
\text { Metal anti personnel } \\
\text { Plastic/metal anti personnel } \\
\text { Metal antitank mine }\end{array}$ & $\begin{array}{c}2 \mathrm{~m} \\
5-50 \mathrm{~m} \\
200 \mathrm{~m}\end{array}$ & $94 \mathrm{GHz}$ ve $140 \mathrm{GHz}$ & $\begin{array}{l}\text { Very close to } \\
\text { surface } \\
(2-5 \mathrm{~mm})\end{array}$ & {$[52]$} \\
\hline Sand & $\begin{array}{c}\text { Land mine } \\
\varnothing 10 \mathrm{~cm} \mathrm{~h}=3.5 \mathrm{~cm}\end{array}$ & $1 \mathrm{~m}$ & $8-14 \mu \mathrm{m}$ & $1.5 \mathrm{~cm}$ & [3] \\
\hline
\end{tabular}


As in the metal detectors, when a RF signal that has a frequency (about in between 0.5 and $6 \mathrm{MHz}$ ) closing to the NQR frequency of the explosive which is found just under the ground is sent through a planar antenna, the energy level of nitrogene changes. When the RF excitation is removed, the nuclei return to their original energy levels and some characteristic radio waves that are specific to the expolosive appear. By using a second antenna designed specifically, the weak radio waves returning from the excited explosive object can be received. The strength of these weak induction currents obtained from the sensor coils determines the amount of explosive. In addition, the frequency of the induction currents gives the type of explosive [53] [54]. Because of the nature of the NQR method, low sensitivity that is a result of low resonant frequencies $(0.5-6 \mathrm{MHz})$ is a big problem [55]. For that reason, powerful detection systems have to be used by this method. Otherwise, it can be easily affected by RF interference. To increase the sensitivity of nitrogene is costly. For example, the price of a Lanthanum detector $(7.62 \times 7.62 \mathrm{~cm})$ is about $\$ 35,000$ and a germanium detector with the same dimensions which is more sensitive than the former is about $\$ 100,000$ [56]. In order to receive a signal from the sensor from a potential explosive, the antenna must be placed directly on the explosive and it has to be close to the ground. Otherwise the information collected for the place and depth of the buried mine will be inaccurate [54]. Therefore, the applications where the buried AP mines are tied to be determined by the NQR method have given bad results [54]. For this reason, this method more practical and fast for the cases where the mine are not buried and found on surfaces. Furthermore, in order to increase the signal to noise ration, it is required to measure the average value of the temperature of the explosive in the mine by using appropriate techniques before scanning and determine it as an input from the sensor. This means that new detectors and algorithms to be developed [54]. In recent studies, non-linear least-meanssquare detector and maximum likelihood detector that can also read the dependencies of the NQR frequencies to the temperature have been developed in order to increase the low signal to noise ratio. It is also possible to avoid from the disturbing effect of fertilizers with nitrogene content in the ground that can give rise to false alarms [44] [57].

In our study, NQR method is investigated for buried land mine detection and again the following variables are selected for performance criteria parameters for each work that is examined: soil type, material tested, test height, working rate and frequency, findings under these conditions [54] [55] [57]. Figure 6 gives the principle of the NQR method for mine detection. Table 5 gives the comparison of performance parameters on the works of detecting land mines.

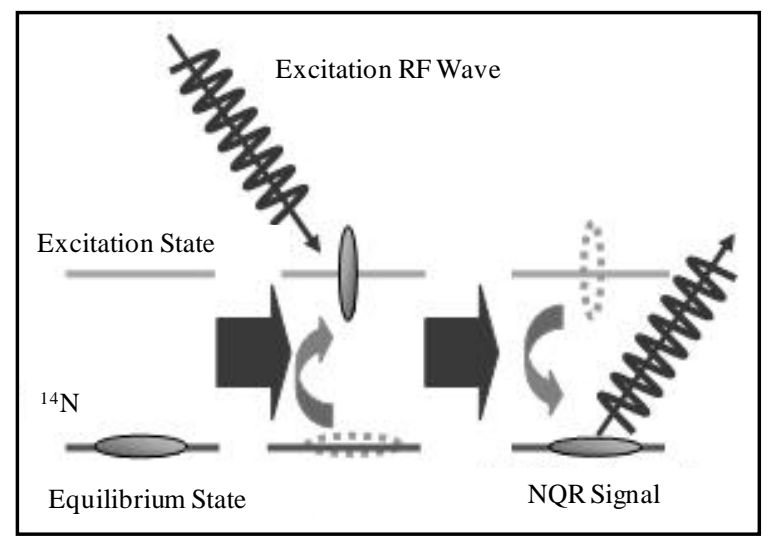

Figure 6. Principle of mine detection by NQR method.

Table 5. Performanceanalysis of mine detection by NQR method.

\begin{tabular}{|c|c|c|c|c|c|}
\hline Soil type & Materials tested & Height of test & $\begin{array}{l}\text { Operating speed or } \\
\text { frequency }\end{array}$ & $\begin{array}{c}\text { Performance of } \\
\text { operation }\end{array}$ & Reference \\
\hline $\begin{array}{l}\text { Garden } \\
\text { soil }\end{array}$ & $\begin{array}{l}\text { Anti tankr }(19 \times 19 \times 7 \mathrm{~cm}) \text { and } \\
\text { anti personnel }(14 \times 14 \times 7 \mathrm{~cm}) \\
\text { minen (sodium nitrade filled) }\end{array}$ & $\begin{array}{l}\text { Above mine, close } \\
\text { to surface }\end{array}$ & $0.5-6 \mathrm{MHz}$ & 3-5-7-8-10 cm & [55] \\
\hline Soil & TNT & $\begin{array}{l}\text { Above mine, close } \\
\text { to surface }\end{array}$ & $0.5-6 \mathrm{MHz}$ & $\begin{array}{l}20 \mathrm{~cm} \text { (explosive can be } \\
\text { determined. Boundaries } \\
\text { and depth are } \\
\text { problematic) }\end{array}$ & [57] \\
\hline
\end{tabular}


As seen from Table 5 that the radio frequency badwith is held at $0.5 \mathrm{MHz}-6 \mathrm{MHz}$. The nitrogen radiation within plastic and metal covered land mines is detected at a height of $20 \mathrm{~cm}$ above the ground. It is observed that soil type may affect the detection depth.

\subsubsection{Thermal Neutron Activation-TNA Method}

This is a method based on the detection of special gamma rays radiated from the nitrogene nucleus found in the structure of many explosives activated by neutron bombardment on the surface of the soil.

Since the explosives have more nitrogene content than the soil (18\% to 38\%), the probability of making an error to detect them is very low. As the content of explosive in AT mine is greater than the content of AP mines, this method is advantageous in detecting AT mines than AP mines. The disadvantages of this system are that it has a complicated structure and weight (180 kg), in addition the detection time with it is long [56] [58] [59]. The TNA method is mostly used in confirming the misgiving or refusing results obtained by faster methods. By this way, false alarm ratios may be reduced to acceptable levels. However, it has to be remembered that the gamma rays are dangerous for living creatures in case they exposed to them, therefore during detection process the distance between a user and the detection system must be at least $4 \mathrm{~m}$ [60].

In our study, thermal neutron activation (TNA) method is investigated for buried land mine detection and again the following variablesareselectedforperformancecriteriaparametersforeachworkthat is examined: soil type, material tested, test height, working rate and frequency, findings under these conditions [56] [59]-[66]. Figure 7 gives the principle of the EMI method for mine detection. Table 6 gives the comparison of performance parameters on the works of detecting land mines.

As seen from Table 6 that in the works, electrons with an energy of about $10-14 \mathrm{MeV}$ are used. The nitrogen based gamma radiation is detected for plastic and metal covered mines at a level of $20 \mathrm{~cm}$ above the sand area. The detection depth may change with the amount of explosive and cover of the mine.

\subsubsection{Neutron Back Scattering Method}

Neutron back scattering method is based on a process in that the electrons of hydrogen present in the structure of the object to be detected are breaked by activating them with the kinetic energy of accelerated electrons by means of a cyclotron and then detecting the electrons with low energy that are backscattered and counting them.

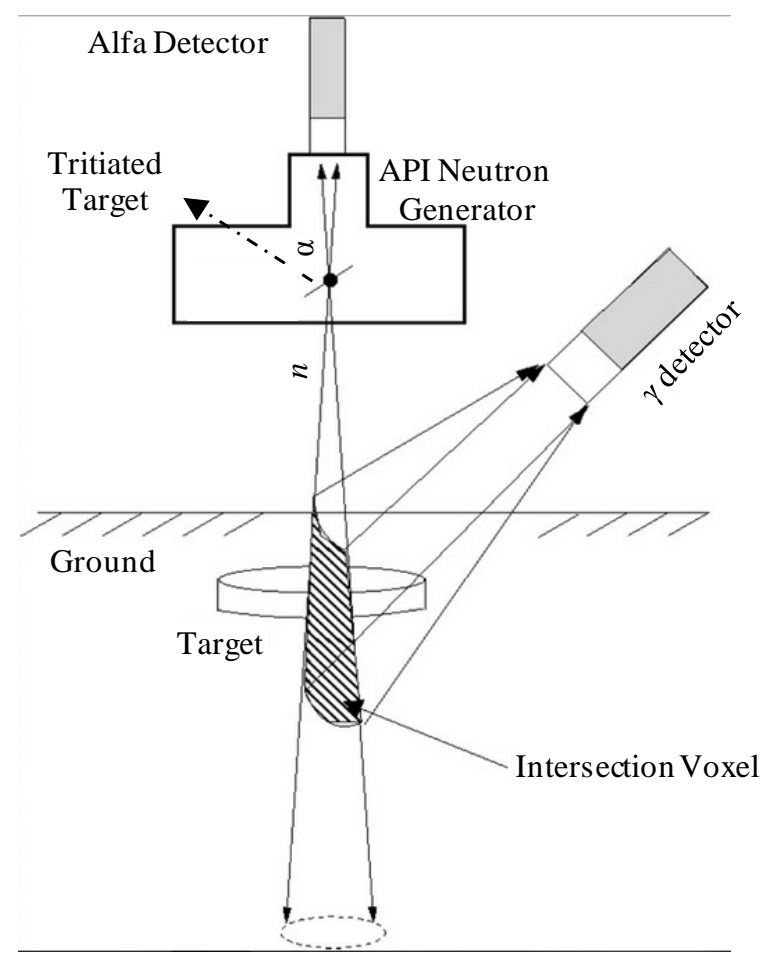

Figure 7. Principle of mine detection by the TNA method. 
Table 6. Performance analysis of land mine detection by thermal neutron activation.

\begin{tabular}{|c|c|c|c|c|c|}
\hline Soil type & Materials tested & Height of testing & $\begin{array}{l}\text { Operation speed } \\
\text { or frequency }\end{array}$ & Performance of study & Reference \\
\hline Sand & Land mine & $12 \mathrm{~cm}$ & $\begin{array}{l}10.8 \mathrm{MeV} \text { gamma } \\
\text { ray }\end{array}$ & $3 \mathrm{~cm}$ & {$[60]$} \\
\hline \multirow[t]{2}{*}{ Sand } & $\begin{array}{c}\text { Anti tank mine } \\
\text { (with } 1 \text { - } 3 \text { kg nitrogene) }\end{array}$ & \multirow[t]{2}{*}{$\begin{array}{l}\text { On the mine, close } \\
\text { to surface }\end{array}$} & \multirow[t]{2}{*}{$\begin{array}{c}9.5-11 \mathrm{MeV} \\
\text { gamma ray }\end{array}$} & $\begin{array}{l}10 \text { cm (1 dakika) } \\
20 \text { cm (5 dakika) }\end{array}$ & \multirow[t]{2}{*}{ [56] } \\
\hline & 100 g nitrogene & & & Yüzeyeserili (5 dakika) & \\
\hline Dry soil & $\begin{array}{c}\text { Anti tank mine }(5.6 \mathrm{~kg}) \\
\text { Anti personnel mine }(200 \mathrm{~g})\end{array}$ & Close to surface & $\begin{array}{l}14 \mathrm{MeV} \text { gamma } \\
\text { ray }\end{array}$ & $\begin{array}{l}7.5 \mathrm{~cm} \\
5 \mathrm{~cm}\end{array}$ & [62] [63] \\
\hline Sand & $\begin{array}{l}\text { M15 (steel) (3.1 kg) } \\
\text { M15 (steel) }(3.1 \mathrm{~kg}) \\
\text { TMA3 (resin) }(1.2 \mathrm{~kg}) \\
\text { TMA3 (resin) }(1.2 \mathrm{~kg}) \\
\text { TMA3 (resin) }(1.2 \mathrm{~kg}) \\
\text { M21 (metal) }(0.9 \mathrm{~kg}) \\
\text { TMA5A (plastic) }(1 \mathrm{~kg})\end{array}$ & $\begin{array}{l}\text { On the mine, close } \\
\text { to surface }\end{array}$ & $\begin{array}{c}10.835 \mathrm{MeV} \\
\text { gamma ray }\end{array}$ & $\begin{array}{c}0 \mathrm{~cm}(2 \mathrm{~s}) \\
10 \mathrm{~cm}(24 \mathrm{~s}) \\
0 \mathrm{~cm}(2 \mathrm{~s}) \\
10 \mathrm{~cm}(28 \mathrm{~s}) \\
20 \mathrm{~cm}(954 \mathrm{~s}) \\
10 \mathrm{~cm}(40 \mathrm{~s}) \\
10 \mathrm{~cm}(69 \mathrm{~s})\end{array}$ & [59] \\
\hline Space & $\begin{array}{c}\text { Teflon buttle } \\
\text { (TP and NB filled) } \varnothing 6 \mathrm{~cm} \mathrm{~h} \\
=2 \mathrm{~cm}\end{array}$ & $25 \mathrm{~cm}$ & $8 \mathrm{MeV}$ gamma ray & $25 \mathrm{~cm}$ & [65] \\
\hline Sand & $\begin{array}{c}\text { Disc } \varnothing 6 \mathrm{~cm} \mathrm{~h}=2 \mathrm{~cm} \\
\left(\mathrm{C}_{3} \mathrm{H}_{6} \mathrm{~N}_{6}, \mathrm{NH}_{4} \mathrm{NO}_{3}, \mathrm{H}_{2} \mathrm{O}\right) \\
\text { Plastic mine } \varnothing 10.2 \mathrm{~cm} \mathrm{~h}=1 \\
\text { cm (222 g Al, } 576 \mathrm{~g} \mathrm{Fe}, 686 \mathrm{~g} \\
\mathrm{Cu}, 863 \mathrm{~g} \mathrm{~Pb})\end{array}$ & $10 \mathrm{~cm}$ & $\begin{array}{l}14 \mathrm{MeV} \text { gamma } \\
\text { ray }\end{array}$ & $0.2-4 \mathrm{~cm}$ & {$[66]$} \\
\hline
\end{tabular}

In this method, the particle to be sent may be a neutron. In this case, it is based on the detection of scattered thermal neutrons with low energy $(0.08 \mathrm{eV})$ as a result of the interaction between the fast neutrons radiated from a neutron generator with active source and the hydrogen nucleus of the explosive.

Since the neutron backscattering is a method based on the determination of hydrogen within an explosive, the special condition is that the soil must be dry. Otherwise, it is difficult to make detection because in a soil with a humidity content of $12 \%$ the hydrogen concentration in soil and hydrogen concentration in mine becomes equal [67]. As a result, the change in humidity and irregularities of surface may give rise to high false alarm ratios. As the source-detector system is heavy, there is a need to install it together with the required electronic equipment on a vehicle [67]. By using this method, the AT mines can easily be detected, however the small mines can be noticed [68] [69]. This method is mostly successful in shallow depths. Therefore, as the detector to be very close to the surface, this method can be used in applications in which there is a reliable base surface [67].

In our study, neutron backscattering method is investigated for buried land mine detection and again the following variables are selected for performance criteria parameters for each work that is examined: soil type, material tested, test height, working rate and frequency, findings under these conditions [67]-[69] [70]-[72]. Figure 8 gives the principle of the EMI method for mine detection. Table 7 gives the comparison of performance parameters on the works of detecting land mines.

As seen from Table 7 that a neutron generator producing neutron with an energy of about $14 \mathrm{MeV}$ is used in the works. Low energy thermal neutrons scattering as a result of interaction with the produced neutrons and explosive can be detected at a height of maximum $20 \mathrm{~cm}$ for sand and wet soil areas. The amount of explosive and cover depth may affect the detection depth.

\subsubsection{X-Ray Back Scattering Method}

This method is based on a process that an X-ray is passed through the object under consideration and the image on a light sensitive film ay the back side of the object is interpreted. However, the image at the back side of a mine is impossible to obtain physically. In this case, an X-ray focused by passing it through an accelerator is sent to the mine buried and the outer cover or the explosive is stimulated. The cover or explosive returns to a base and gives the energy that it received back. The X-ray is passed again through another accelerator and arrived at the detector where the related image is formed. As a matter of fact, the X-rays from regions where the densities are different will vary in strength. Depending on the strength, a two-dimensional image of the region 


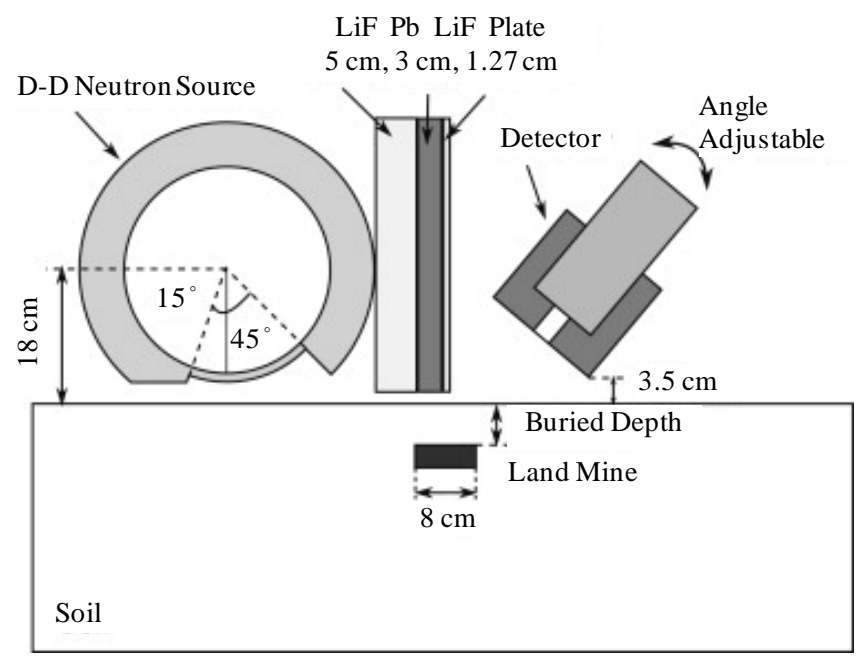

Figure 8. Principle of neutron back scattering method.

Table 7. Performance analysis of land mine detection by neutron back scattering method.

\begin{tabular}{|c|c|c|c|c|c|}
\hline Soil type & Materials tested & Height of testing & $\begin{array}{l}\text { Operation speed or } \\
\text { frequency }\end{array}$ & Performance of study & Reference \\
\hline Space & $\begin{array}{l}\text { Cylinder Ø10 cm } \\
\mathrm{h}=10 \mathrm{~cm}\end{array}$ & $1 \mathrm{~m}$ & $\begin{array}{l}14 \mathrm{MeV} \text { neutron } \\
\text { generator }\end{array}$ & $1.5 \mathrm{~cm}$ & {$[70]$} \\
\hline Sand & $\begin{array}{c}\text { Anti personnel mine } \\
\text { (MN-AP-NR-22) Ø6.2 cm } \\
\mathrm{h}=3 \mathrm{~cm} \\
\text { Anti tank mine } \\
\text { (MN-AT-NR-26) Ø30 cm } \\
\mathrm{h}=15 \mathrm{~cm}\end{array}$ & $5 \mathrm{~cm}$ & $\begin{array}{l}14 \mathrm{MeV} \text { neutron } \\
\text { generator }\end{array}$ & $3-5 \mathrm{~cm}$ & [69] \\
\hline Sand & $\begin{array}{c}\text { Anti tank mine } \varnothing 20 \mathrm{~cm} \\
\mathrm{~h}=4 \mathrm{~cm} \\
\text { Anti personnel mine } \\
\text { DLM2.2 Ø8 cm h = } 3.4 \mathrm{~cm}\end{array}$ & $\begin{array}{l}\text { On the mine, } \\
\text { close to surface }\end{array}$ & $\begin{array}{c}0.33-3.33 \mathrm{KHz} \\
\text { neutron generator }\end{array}$ & $\begin{array}{l}20 \mathrm{~cm} \\
10 \mathrm{~cm}\end{array}$ & {$[67]$} \\
\hline Soil & $\begin{array}{l}\text { Anti personnel mine }(200 \mathrm{~g}) \\
\text { Anti tank mine }(5.6 \mathrm{~kg})\end{array}$ & $\begin{array}{l}\text { On the mine, } \\
\text { close to surface }\end{array}$ & $\begin{array}{l}10.8 \mathrm{MeV} \text { neutron } \\
\text { generator }\end{array}$ & $\begin{array}{c}5 \mathrm{~cm} \\
7.5 \mathrm{~cm}\end{array}$ & {$[72]$} \\
\hline $\begin{array}{c}\text { Soil \%2-\%10-\%18.5 } \\
\text { wet }\end{array}$ & $\begin{array}{l}\text { RDX (29 g, } 100 \text { g) } \\
\text { TNT (100 g, } 240 \text { g) }\end{array}$ & $3.5 \mathrm{~cm}$ & $\begin{array}{l}\text { 14.1 MeV neutron } \\
\text { generator }\end{array}$ & $\begin{array}{c}\text { 5-10-15 cm } \\
\text { (confidence level \%68) }\end{array}$ & [73] \\
\hline
\end{tabular}

can be obtained. However, detection accuracy, low penetration depth, multiple targets, slope of area and height of the detection cap may cause some problems to be encountered [74] [75]. Metal covered land mines have lower absorbtion-scattering ratio than the plastic mines and soil, their detection by this method is much more difficult [2]. Because of the long determination time (about $22 \mathrm{~min}$ ), the recent studies have been concentrated on obtaining a good quality of images in a shorter time [75]. Speeding up the process may increase the system weight and volume, but decrease X-ray density. A system detecting an explosive by back scattering is shown schematicallyin Figure 10.

In our study, X-ray backscattering method is investigated for buried land mine detection and again the following variables are selected for performance criteria parameters for each work that is examined: soil type, material tested, test height, working rate and frequency, findings under these conditions [74] [75] [76]-[83]. Figure $\mathbf{9}$ gives the principle of the X-ray method for mine detection. Table 8 gives the comparison of performance parameters on the works of detecting landmines

As seen in Table 8 that X-rays with an energy of about $150 \mathrm{keV}$ is used in the works. In dry soil, X rays radiated from the explosive within the mine can be detected at a height of maximum $3 \mathrm{~cm}$. The amount of explosive and cover may change the detection depth. 


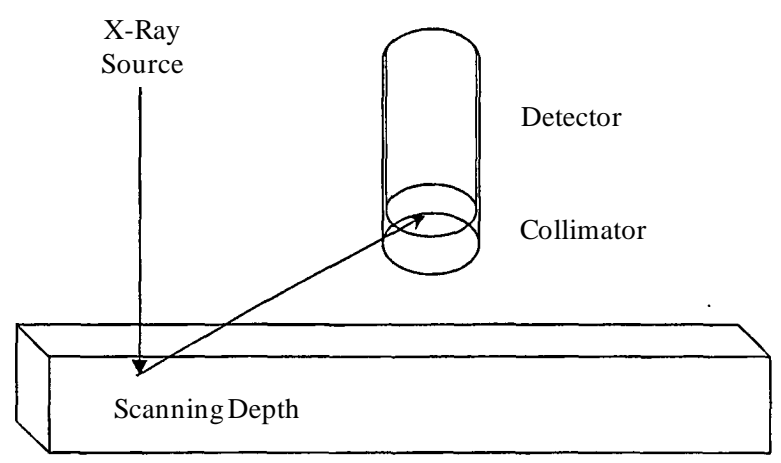

Exemplary Geometrical Focusing Schematic

Figure 9. Explosive detection by back scattering method.

Table 8. Performance analysis of şand mine detection by X-ray backscattering method.

\begin{tabular}{|c|c|c|c|c|c|}
\hline Soil type & Materials tested & Height of testing & $\begin{array}{l}\text { Operation speed or } \\
\text { frequency }\end{array}$ & $\begin{array}{c}\text { Performance of } \\
\text { study }\end{array}$ & Reference \\
\hline Dry loose soil & $\begin{array}{l}\text { PMA-2 Ø6.8 cm (70 g TNT } \\
\text { strengthen with steel balls) }\end{array}$ & $4 \mathrm{~cm}$ & 20 - $120 \mathrm{KeV}$ photon energy & $1 \mathrm{~cm}$ & {$[74]$} \\
\hline Soil & $\begin{array}{l}\text { Cylindirical metal } \varnothing 8 \mathrm{~cm} \\
\mathrm{~h}=0.5 \mathrm{~cm}\end{array}$ & $60 \mathrm{~cm}$ & $\begin{array}{l}0 \text { - } 300 \mathrm{KeV} \text { photon energy } \\
\text { (source } 120 \mathrm{kV}_{\mathrm{p}} 3 \mathrm{~mA} \text { ) }\end{array}$ & $1 \mathrm{~cm}$ & {$[76]$} \\
\hline Soil & $\begin{array}{l}\text { TS-50 anti personnel mine } \\
\text { TMA-4 ve M-19 anti tank mine }\end{array}$ & $30.5 \mathrm{~cm}$ & Source $150 \mathrm{kV}_{\mathrm{p}} 140 \mathrm{~W}$ & $\begin{array}{c}\text { Laid down on } \\
\text { surface } 3 \mathrm{~cm}\end{array}$ & {$[75]$} \\
\hline
\end{tabular}

\subsection{Magnetic Anomaly Method (MAD)}

Research on magnetic sensors with medium sensitivity appears as the studies for determining magnetic anomaly. Magnetic anomaly method is based on the detection of changes in magnetic field by an object with ferromagnetic characteristics exposed to an external magnetic field. Any decrease in flux density at the region where a magnetic object exists can give rise to an electrical change in the sensor. As a result, the output voltage of the sensor will change. By interpreting these changes, it is possible to have information on the place, dimensions and, if applicable, the other characteristics of an object with magnetic characteristics. Ferromagnetic materials can be divided into two classes as being hard and soft materials. Hard magnetic materials can preserve their magneticity after the magnetic field is removed. However, soft materials may lose their magneticities after the removal of the magnetic field. Therefore, magnetic permeability of soft materials is greater than the hard ferromagnetic materials. When an external magnetic field is applied, the magnetic flux will be denser in regions where magnetic permeability is high. In Figure 10, it is seen how a submarine within a magnetic field of the earth may change the flux lines by collecting them towards it.

In MAD method, different sensors such as MR, SQUID, Hall and coil can be used to detect magnetic anomaly [84]. In this method, low energy consumption, low cost, insensitivity to environmental changes, high sensitivity, fast sensing, reliability and robustness are essential factors. Taking into account these facts, the main purpose of the research in this area is the identification of the ferromagnetic materials creating magnetic anomaly. The system required is composed of a moving platform, a sensing mechanism and an electronic unit converting the data into electrical signals. Since the silicon based sensors cost about several cents, this method may be the most cost effective solutions among the other methods. In addition, as the moving platform carries only the small sensors, it is very small in size and portable ( $1-2 \mathrm{~kg}$ ). All the data can be processed by simple PICs, hence the system can be implemented as simple unit. Since it is a lightweight system, it can be moved easily and faster. In most of the applications, a 24 bit ADC is more than enough $(500 \mathrm{nV})$. Power requirement of such a system is very low $(3,12 \mathrm{~W})$. In addition to the advantages mentioned above, interoperability of it with the other sensing systems is its invaluable property.

In military area, magnetic anomaly method is used in detecting of land and naval mines, unexploded munitions, detecting submarines [85]-[90]. In our study, the works done in this area are investigated and the performance parameters are evaluated. In Table 9, performance analysis of this method can be seen. 


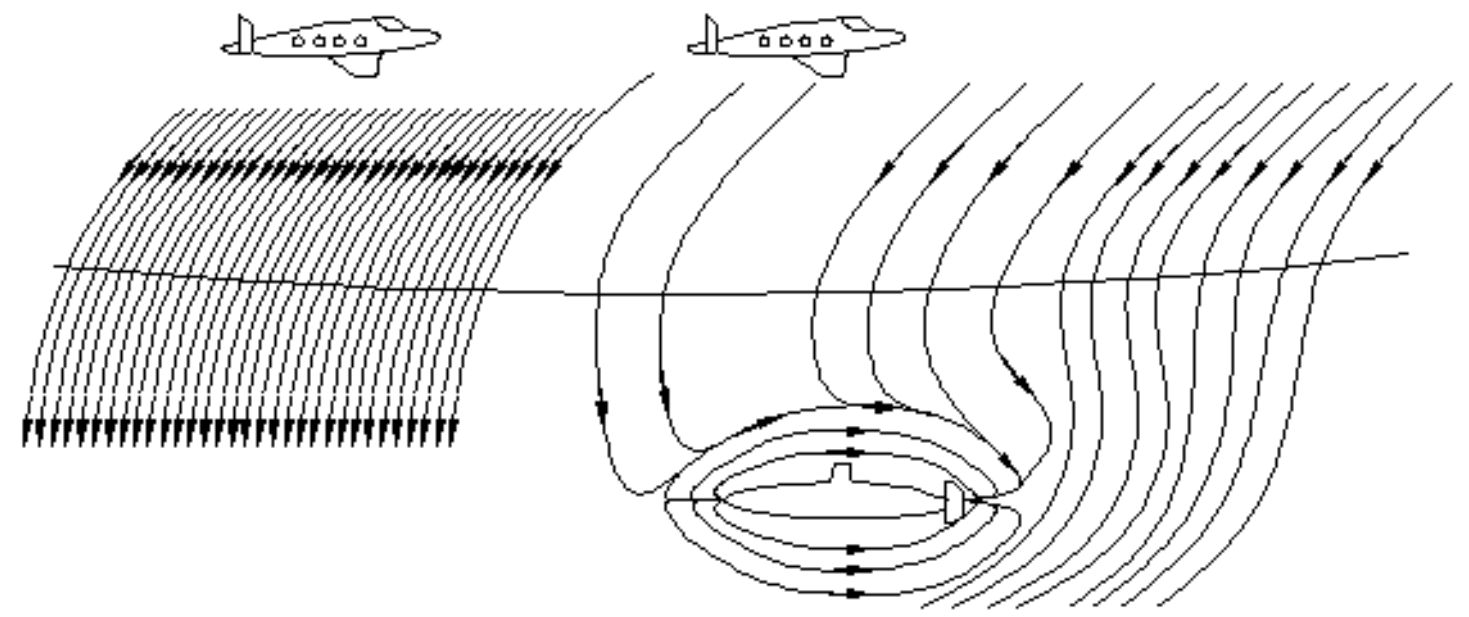

Figure 10. The change of earth's magnetic field by a submarine.

Table 9. Performance analysis of mine detection by magnetic anomaly method.

\begin{tabular}{|c|c|c|c|c|c|}
\hline Soil type & Materials tested & Height of testing & $\begin{array}{l}\text { Operation speed } \\
\text { or frequency }\end{array}$ & Performance of study & Reference \\
\hline Water & Pipe & $12 \mathrm{~m}$ & $3-25 \mathrm{kHz}$ & One food buried in sand & [85] \\
\hline Space & M2, M16 anti personnel mine & $1-13 \mathrm{~cm}$ & - & $13 \mathrm{~cm}$ & [88] \\
\hline Space & $\begin{array}{l}\text { Aluminum } 5 \times 5 \times 0.15 \mathrm{~cm} \\
\text { Iron nail } 3 \times 0.3 \mathrm{~cm}\end{array}$ & $\begin{array}{l}20 \mathrm{~cm} \\
10 \mathrm{~cm}\end{array}$ & $1 \mathrm{kHz}$ & $\begin{array}{l}20 \mathrm{~cm} \\
10 \mathrm{~cm}\end{array}$ & [89] [90] \\
\hline
\end{tabular}

As seen in Table 9 that the AC current frequency supplying magnetic field is chosen as $1-25 \mathrm{kHz}$. The magnetic anomaly created by the covers of land mined can be detected from a height of maximum $20 \mathrm{~cm}$ for water and air. The magnetic permeability of may change the test depth.

\section{Algorithms Used for Mine Classification}

In subsurface mine detection problems, there are several numerical methods based on the solution of electromagnetic (EM) field problems to analyze the scattering by homogeneous bodies. Among them the most efficient numerical techniques may be the transmission line matrix (TLM), the finite difference time-domain (FDTD), the method of momentum (MoM), and the split step parabolic equation (SSPE) methods.

One of the most efficient numerical techniques to analyze the scattering by homogeneous bodies is the surface integral equation numerically evaluated by the method of momentum (MoM) [91]. As a special case, the minimum number of basis functions for convergence of the method of moments (MoM) analysis of EM scattering by bodies of revolution is investigated in [92]-[94]. Although EM scattering from conducting, dielectric, and composite bodies have been successfully studied using MoM [95]-[97], they are often limited to small geometries and small relative permittivities $\left(\varepsilon_{r}\right)$, and the optimal number of basis functions has not been addressed. The method of moment (MoM) is one of the methods for the analysis of the array antennas [98]. In that paper, when the array antenna has Nantenna elements and each element is divided into $\mathrm{M}$ segments for the subdomain MoM analysis, $N_{T} \times N_{T}$ matrix equation has to be solved to obtain the unknown current vector, where $N_{T}=M \times N$. Iterative methods [99] in computational EMs has led to the publication of a variety of papers on the available iterative algorithms. One iterative algorithm, the conjugate gradient method (CGM) [100], is currently a focal point for much work in the area. The study in [99] attempts to complement the method in [100] by characterizing the typical numerical convergence rates of the CGM when applied to equations representing a wide variety of EM scattering problems.

Detection of mines or subsurface objects by for example GPR, which are mostly used within multi-area, multi-sensor, land-based, maritime and/or air-based integrated complex systems requires the modelling of EM wave propagation over realistic earth's surface through a radially inhomogeneous atmosphere. Ground wave propagation changes due to the ground effects. The variability of the ground characteristics and terrain profiles as well 
as those of the overlying atmospheric layers render the problem non-tractable via exact analytical methods. In [101], it is claimed that the only analytical approximate solutions, such as ray and mode theories [102] exist. However, a full-wave, observable based and numerically computable solution has not appeared yet. L. Sevgi, et al. introduced a two-dimensional, parabolic equation (PE) technique, which is called split step parabolic equation (SSPE) [103]. It is an alternative to ray-mode methods. In that paper, SSPE method is explained with the necessary modifications required for modelling propagation over irregular terrain and applied for typical as well as complex propagation scenarios. Other propagation models capable of accounting for horizontal refractive gradients may be found in the literature, but they are restricted to simplistic refractive conditions, lower frequencies and/or certain regions of space. The use of parabolic equation (PE) for EM wave propagation in a vertically inhomogeneous medium was described by Leontovich and Fock [104]. However, their approach has not been famous until after the introduction of the Fourier Spit Step algorithm by Tappert [105] [106], who solved the acoustic parabolic wave equation with this method numerically, because the scalar parabolic equation associated with EM propagation in troposphere is, within a good approximation, the same as the one used to describe acoustic wave propagation in the ocean.

Transmissions line matrix (TLM) are finite difference time domain (FDTD) are the other efficient techniques for the solution of scattering problems. TLM is a space and time-domain method. It is based on the analogy between the EM field and a mesh of transmission lines. Modeling the EM field problems using electrical networks were established long time ago [107]-[109]. They were analytical solutions. Some numerical solutions had been developed with the introduction of digital computers [110]-[115]. In TLM method, voltage pulses are used to calculate EM field components. It is based on electrical network theory. In the TLM, each node is represented by a scattering matrix. However, in FDTD, EM components are calculated directly. It is based on field theory. The field components are located at different positions in the cell [116]. In recent years, developed image processing techniques and intelligent algorithms and systems such as neural networks have also been widely used in identifying objects effectively [117]-[119]. In the following, we summarize the above mentioned methods shortly.

\subsection{Transmission Line Matrix (TLM)}

Transmission line matrix (TLM) is a numerical time-domain technique that is widely used to analyse GPR concept. TLM is normally a space and time discretization method for computing EM field scattering. It uses the analogy between the EM field and an electrical network namely a transmission line equations. A transmission line (TL) ended with a load is shown in Figure 11(a).

The characteristic impedance of the TL is $Z_{0}$. The reflection coefficient $\Gamma_{L}$ can be defined as in Equation (3)

$$
\Gamma_{L}=\frac{V^{-}(x=0)}{V^{+}(x=0)}=\rho_{L} \mathrm{e}^{j \varphi_{L}}
$$

where $V^{+}(x=0)$ is the incident voltage wave at $x=0$, and

$V^{-}(x=0)$ is the reflected voltage wave at $x=0$,

$\Gamma_{L}$ is a complex quantity with a magnitude of $\rho_{L}$ and an angle of $\varphi_{L}$.

$\Gamma_{L}$ can easily be represented by the impedances as in Equation (4):

$$
\Gamma_{L}=\frac{Z_{L}-Z_{0}}{Z_{L}+Z_{0}}
$$

When three equal loads are connected in parallel with each other to the TL as in Figure 11(b), the equivalent impedance becomes

$$
Z_{\text {eq }}=\frac{Z_{L}}{3}
$$

If we consider that the load impedances are $Z_{L}=Z_{0}$, then the equivalent impedance becomes

$$
Z_{\text {eq }}=\frac{Z_{0}}{3}
$$

In this case, the reflection coefficient is 


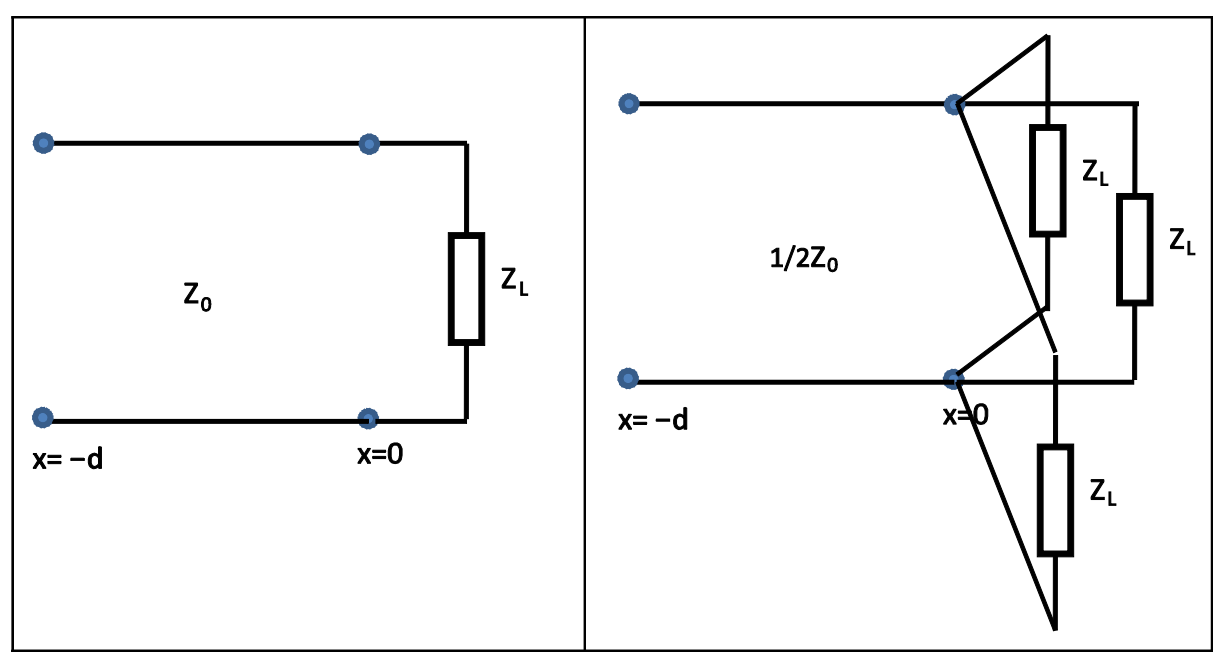

Figure 11. (a) A transmission line with a load; (b) Parallel connection of three identical loads.

$$
\Gamma_{L}=\frac{Z_{0} / 3-Z_{0}}{Z_{0} / 3+Z_{0}}=\frac{-2 Z_{0}}{4 Z_{0}}=-\frac{1}{2}
$$

We can say from Equation (7) that the half of the energy is reflected from the load. By using this analysis, we can make an analogy between the EM field and the network of the TL. We can model the three parallel impedances (each of which is of $Z_{0}$ ) as in Figure 12. In this model, $V^{+}$is the incident voltage pulse. Half of it is reflected at the nodal point.

A plane TEM wave of infinite extend may be represented by a rectangular matrix with boundaries of the form shown in Figure 13.

If the voltage impulses $V_{j}^{+}(k)$, on lines $j=1, \cdots, 4$ are incident on any junction node in the transmission line at time $k$, then the combined voltage reflected in line 1 at time $(k+1)$ will be [110]

$$
V_{1}^{-}(k+1)=\frac{1}{2}\left[\sum_{j=2}^{4} V_{j}^{+}(k)-V_{1}^{+}(k)\right]
$$

If this pulse is reflected from a node at position $(z, x)$ in the matrix, then it becomes an incident pulse on node $(z, x-1)$, that is

$$
V_{1}^{-}(k+1, z, x)=V_{3}^{+}(k+1, z, x-1)
$$

Similarly, the other lines can be written. For the boundaries, for example at node $(p, q)$ :

$$
V_{j}^{-}(k, p, q)=V_{j}^{-}(k, p, q \pm 1)
$$

where \pm indicates upper boundary for $(-)$ and lower boundary for $(+)$.

\subsection{Finite Difference Time-Domain (FDTD)}

The finite difference method is based on the replacement of Maxwell's equations into a set of finite difference equations [115]. Because of the huge processing and memory capacity of today's computers, it is now possible to solve these difference equations more easily than the early day's approaches.

The famous Maxwell's equations in an isotropic medium are

$$
\begin{gathered}
\frac{\partial B}{\partial t}+\nabla \times E=0 \\
\frac{\partial D}{\partial t}-\nabla \times H=J \\
B=\mu H
\end{gathered}
$$




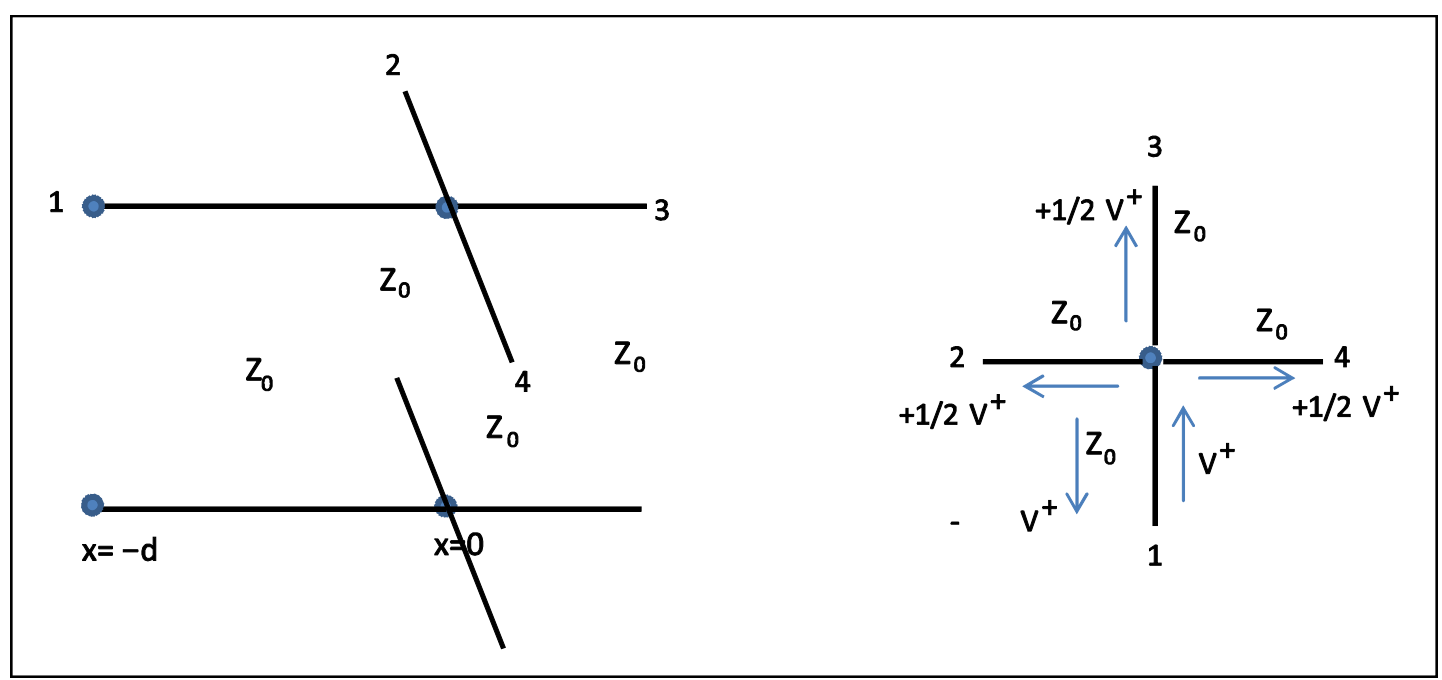

(a)

(b)

Figure 12. (a) Model of the transmission line with three parallel impedances; (b) Upper view.

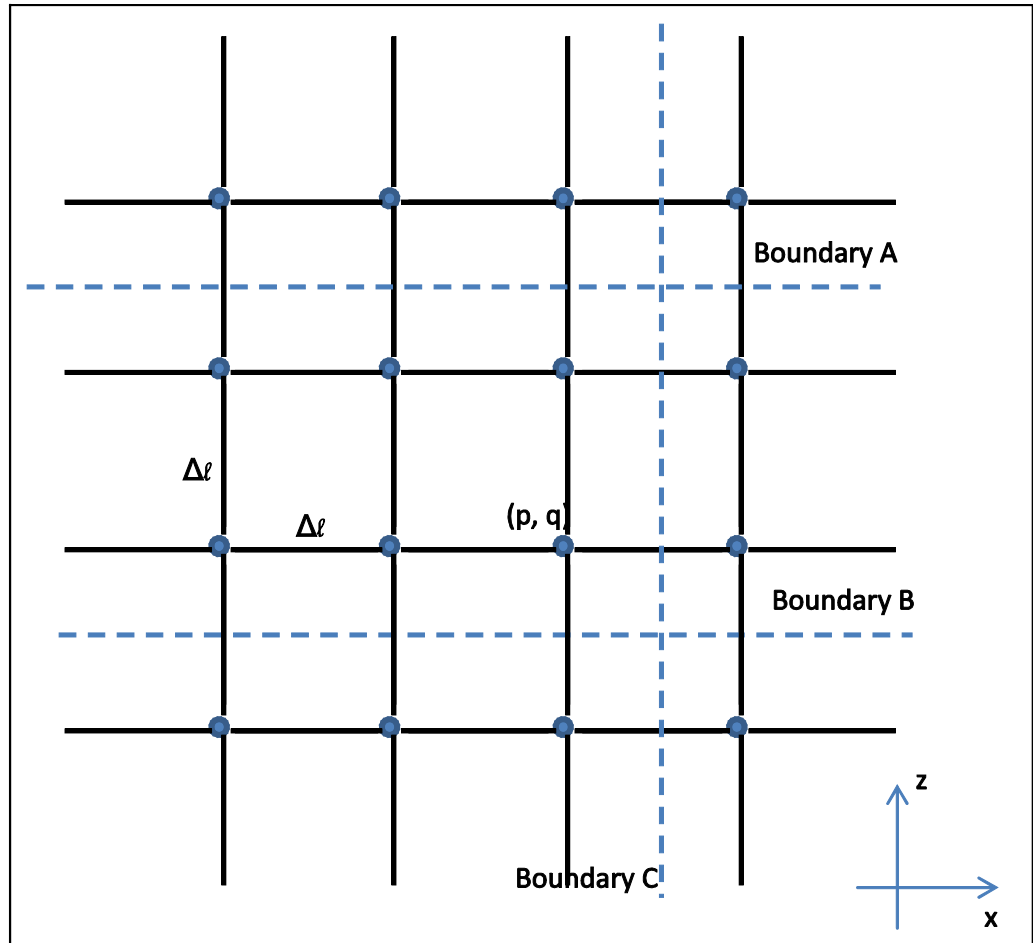

Figure 13. Transmission line matrix and boundaries.

$$
D=\varepsilon E
$$

where boldface letters represent vector quantities in 3-dimension. These vector quantities are functions of space and time. We can use the following notation for the scalar rows of them:

$$
F(n \Delta t, i \Delta x, j \Delta y, k \Delta z)=F(n, i, j, k)
$$

where $n$ is discrete time and $(i, j, k)$ are orthogonal unit vectors. Using this notation we can write, for example, the finite difference equation for the scalar equation of $x$ component of Equation (11) for perfectly conducting boundary condition as follows: 


$$
\begin{aligned}
\frac{1}{\Delta t}\left[B_{x}\left(n+\frac{1}{2}, i, j+\frac{1}{2}, k+\frac{1}{2}\right)-B_{x}\left(n-\frac{1}{2}, i, j+\frac{1}{2}, k+\frac{1}{2}\right)\right]= & \frac{1}{\Delta z}\left[E_{y}\left(n, i, j+\frac{1}{2}, k+1\right)-E_{y}\left(n, i, j+\frac{1}{2}, k\right)\right] \\
& -\frac{1}{\Delta y}\left[E_{z}\left(n, i, j+1, k+\frac{1}{2}\right)-E_{z}\left(n, i, j, k+\frac{1}{2}\right)\right] .
\end{aligned}
$$

The other finite difference scalar equations for components $B_{y}$ and $B_{z}$ cab be written in the similar manner. The finite difference equations for scalar rows of Equation (12)

$$
\begin{aligned}
\frac{1}{\Delta t}\left[D_{x}\left(n, i+\frac{1}{2}, j, k\right)-D_{x}\left(n-1, i+\frac{1}{2}, j, k\right)\right]= & -\frac{1}{\Delta z}\left[H_{y}\left(n-\frac{1}{2}, i+\frac{1}{2}, j, k+\frac{1}{2}\right)-H_{y}\left(n-\frac{1}{2}, i+\frac{1}{2}, j-\frac{1}{2}, k\right)\right] \\
& +\frac{1}{\Delta y}\left[H_{z}\left(n-\frac{1}{2}, i+\frac{1}{2}, j+\frac{1}{2}, k\right)-H_{z}\left(n-\frac{1}{2}, i+\frac{1}{2}, j, k+\frac{1}{2}\right)\right] \\
& +J_{x}\left(n-\frac{1}{2}, i+\frac{1}{2}, j, k\right) .
\end{aligned}
$$

The other scalar difference equations can be written similarly.

The grid points for E-field and H-field are shown in Figure 14.

\subsection{Method of Momentum (MoM)}

The method of moment (MoM) is another efficient method for the analysis of electromagnetic problems such as the arrays of antennas. Nice iterative algorithms have been developed and can be applied to scattering problems [91]. In this analysis, groups of several neighboring array elements are constituted. For each group, the sub matrices are decomposed from the impedance matrix. The diagonal submatrices and off-diagonal submatrices represent the self and mutual impedance of the same group, and different groups respectively. The submatrices are the basic iteration units. If each group consists of $K$ elements, and the total array elements are divided into $N / K$ groups completely, the iterating procedure can be expressed as

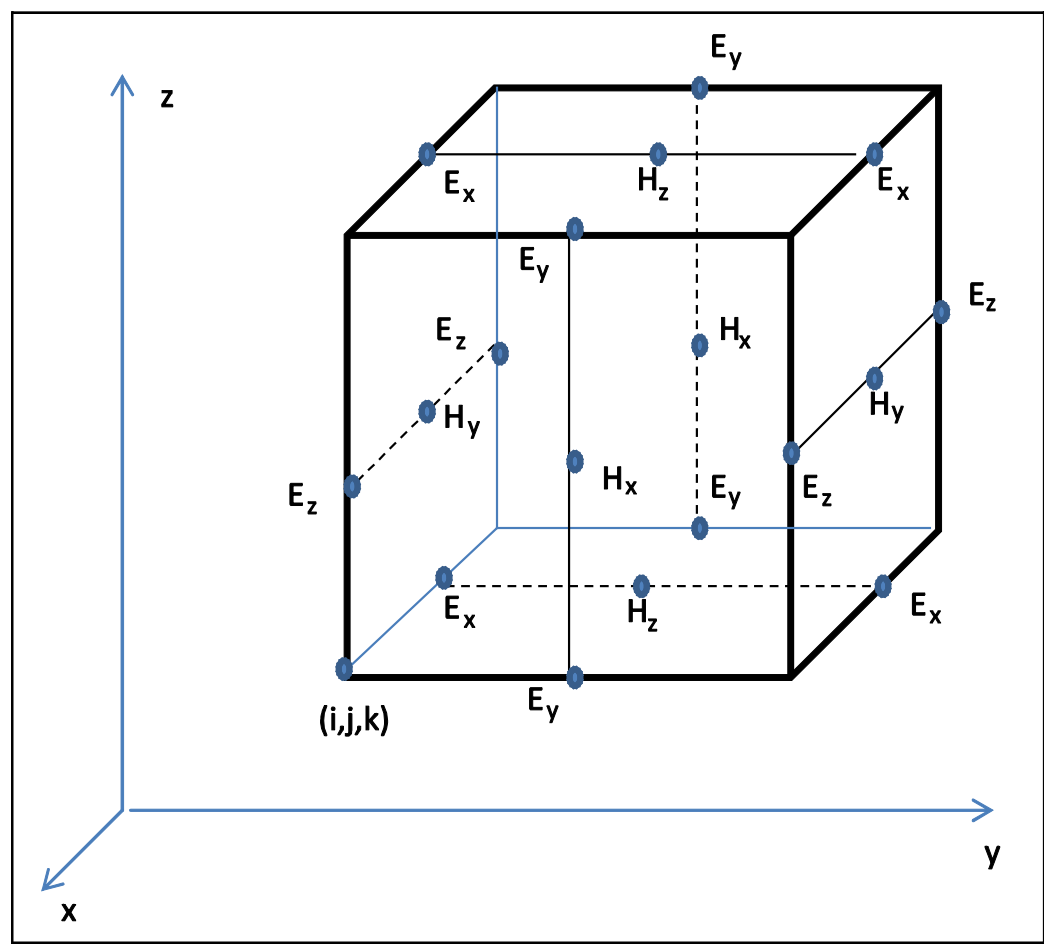

Figure 14. Positions of various field components. 


$$
[\bar{I}]_{i}^{\left(l_{s}+1\right)}=[\bar{Z}]_{i i}^{-1}\left[[\bar{V}]_{i}-\sum_{j=1}^{i-1}[\bar{Z}]_{i j}[\bar{I}]_{j}^{\left(l_{s}+1\right)}-\sum_{j=1}^{N / K}[\bar{Z}]_{i j}^{\left(l_{s}\right)}\right]^{\mathrm{T}} \quad i=1 \text { to } N / K \text { and } l_{s}=1 \text { to } L_{s}
$$

where, $[\bar{I}]_{i}$ is a $\frac{N}{K}$ current vector of the group $i,[\bar{V}]_{i}$ is voltage vector of the group $i,[Z]_{i j}$ is a $\frac{N}{K} \times \frac{N}{K}$ matrix whose elements are the self and mutual impedance between the segments of two groups $i$ and $j$. $[\bar{Z}]_{i i}^{-1}$ can be calculated using a direct method.

\subsection{Split Step Parabolic Equation (SSPE)}

Parabolic equation methods are applied to model propagation over terrain. The equation that must be solved is

$$
\frac{\partial^{2} \psi}{\partial z^{2}}+2 i k_{0} \frac{\partial \psi}{\partial x}+k_{0}^{2}\left(n^{2}-1\right) \psi=0
$$

where $k_{0}$ is the free-space wavenumber, $n$ is the index of refraction, $\psi$ represents a scalar component of the electric field, and $x$ and $z$ are the spatial Cartesian coordinates corresponding to range and height, respectively [104]. The boundary condition is

$$
\psi(x, z=f(x))=0
$$

where $f(x)$ describes the terrain. Let's simplify the issue by mapping range-dependent terrain coordinate system to a flat earth coordinate system. Now, we have a modified parabolic equation subject to a simpler boundary condition. The field is then vanishes at the surface and it is range independent in the new coordinate system. We can solve the problem now by using the split-step method [120]. Let's change the variables to make the coordinate transformation

$$
\begin{aligned}
& \bar{X}=x, \\
& \bar{Z}=z-f(x), \\
& f(x)=t(x)-\frac{x^{2}}{2 a} .
\end{aligned}
$$

Scalar component of the field in new coordinate system

$$
\psi(x, z)=\bar{\psi}(\bar{x}, \bar{z}) \mathrm{e}^{i \bar{\psi}(\bar{x}, \bar{z})}
$$

The function $t(x)$ is the actual terrain and can be any digitized set of height/range points.

$\frac{x^{2}}{2 a}$ takes into account the earth's curvature where a is the radius of the earth.

\subsection{Image Processing and Intelligent Algorithms}

Recently, image processing method is very suitable for analyzing magnetic anomalies created by buried objects [119]. The measurement process can be modeled as a 2-D fictitious sampler for mathematical convenience. The discrete 2-D data obtained by the sensor network can be written as

$$
r^{*}(x, y)=\sum_{k=0}^{n} \sum_{l=0}^{m} r_{k, l} \delta_{k, l}\left[\left(x-k T_{1}\right),\left(y-l T_{2}\right)\right]
$$

where $n$ is the number of impulses in the $x$-direction and $m$ is the number of impulses in the $y$-direction, respectively. Normally, the summations go to infinity, but the terrain of measurement has finite dimensions. The input in (11) is applied to the computer that functions as a 2-D ZOH, and a staircase 2-D continuous spatial function can be obtained

$$
c(x, y)=\sum_{k=0}^{n} \sum_{l=0}^{m} r_{k, l}\left\{u\left[\left(x-k T_{1}\right),\left(y-l T_{2}\right)\right]-u\left[\left(x-k T_{1}-T_{1}\right),\left(y-l T_{2}-T_{2}\right)\right]\right\}
$$

Note that a general nth-order holder could be used for the accuracy of the application. However, in the context of this paper, the use of a $\mathrm{ZOH}$ is well enough and shows the basic approach. After obtaining the measured data 
in continuous form at the output of a 2-D ZOH, it can be smoothed further in order to process in later stages. The smoothing process is a 2-D enhancement with a $3 \times 3$ convolution mask operation applied to $c(x, y)$. The smoothing can be achieved by a "neighborhood averaging" procedure. The output of the smoothing operation is a magnetic distribution having well highlighted objects inside it. Then object identification algorithm is applied.

\section{Discussion}

In this study, application principles of remote detection techniques are given, the academic works carried out using these techniques are investigated and performance achieved for detecting mines by these techniques are determined. In our study, the following variables are selected for performance criteria parameters for each work that is examined: soil type, material tested, test height, working rate and frequency, findings under these conditions.

The methods such as acoustic seismic, GPR, EMI, IR and MAD are used mainly for detecting mine cover, on the other hand the neutron based methods such as NQR, TNA, Neutron Backscattering and X-ray Backscattering are focused on detecting explosives foundwithinthemines. Taking into account the previous academic works as well, all the results for maximum performances are listed in Table 10. The equipment and costs for the methods are given in Table 11.

Table 10. Maximum performances reached by remote detection techniques.

\begin{tabular}{|c|c|c|c|c|}
\hline Method & Place & Detected object & Application frequency & $\begin{array}{c}\text { Maksimum } \\
\text { detection height }\end{array}$ \\
\hline Acoustic-sesimic & Sand or soil & Plastic or mine cover & $450 \mathrm{~Hz}$ sound wave & $5 \mathrm{~cm}$ \\
\hline GPR & Sand, clay and wet soil & Plastic or mine cover & 1 - $5 \mathrm{GHz}$ radio wave & $20 \mathrm{~cm}$ \\
\hline EMI & Sandy and clay soil & Metal mine cover & $\begin{array}{c}300 \mathrm{~Hz} \text { - } 2 \mathrm{GHz} \text { bandwidth } \\
\text { secondary magnetic field }\end{array}$ & $10 \mathrm{~cm}$ \\
\hline IR & $\begin{array}{l}\text { Sandy and soil with } \\
\text { grass }\end{array}$ & Plastic or metal mine cover & $\begin{array}{c}3 \mathrm{MHz} \text { - } 140 \mathrm{GHz} \text { band range } \\
\text { infrared wave }\end{array}$ & $5 \mathrm{~mm}-20 \mathrm{~cm}$ \\
\hline NQR & Mixed soil & Plastic or metal mine cover & $\begin{array}{l}0.5 \mathrm{MHz} \text { - } 6 \mathrm{MHz} \text { band range } \\
\text { radio wave }\end{array}$ & $20 \mathrm{~cm}$ \\
\hline TNA & Sandy soil & $\begin{array}{l}\text { Plastic or metal mine cover } \\
\text { with its explosive }\end{array}$ & 10 - $14 \mathrm{MeV}$ energy electronsr & $20 \mathrm{~cm}$ \\
\hline $\begin{array}{c}\text { Neutron } \\
\text { backscattering }\end{array}$ & Sandy and wet soil & $\begin{array}{l}\text { Plastic or metal mine cover } \\
\text { with its explosive }\end{array}$ & 10 - $14 \mathrm{MeV}$ energy neutrons & $20 \mathrm{~cm}$ \\
\hline $\begin{array}{c}\text { X-ray } \\
\text { backscattering }\end{array}$ & Dry soila & $\begin{array}{l}\text { Plastic or metal mine cover } \\
\text { with its explosive }\end{array}$ & 150 keV energy X-raysı & $3 \mathrm{~cm}$ \\
\hline MAD & Soil, water and air & Plastic or metal mine cover & 1 - $25 \mathrm{kHz}$ band AC source & $20 \mathrm{~cm}$ \\
\hline
\end{tabular}

Table 11. Cost of the equipment for each technique.

\begin{tabular}{|c|c|c|}
\hline Method & Equipments & Unit price \\
\hline Acoustical seismic & Laser-doppler vibration transdusers & $21,000 \$$ \\
\hline Ground penetration radar & GPR system, transmitter antennas & $25,000 \$$ \\
\hline Electromagnetic induction & Induxtion coil, magnetometer, conduction meter & $10,000 \$$ \\
\hline Infrared imaging & Thermal camera & $15,000 \$$ \\
\hline Neutral quadruple resonance & RF exciter, detector & $14,000 \$$ \\
\hline Thermal neutron activation & Electron accelerator, gamma detector & $20,000 \$$ \\
\hline Neutron backscattering & Electron accelerator, electron detector & $23,000 \$$ \\
\hline X-ray backscattering & X-ray source, backscattering detector & $14,000 \$$ \\
\hline Magnetic anomaly & $\begin{array}{l}\text { External magnetic field source, magnetic detectors, } \\
\text { mechanical system }\end{array}$ & $10,000 \$$ \\
\hline $\begin{array}{c}\text { Magnetic anomaly (without using any external } \\
\text { magnetic) }\end{array}$ & Sensors, mechanical system & $3000 \$$ \\
\hline
\end{tabular}


As seen from Table 10, the maximum detection height for each method is about $20 \mathrm{~cm}$. Under appropriate environmental conditions (such as soil type, burrying depth, soil without grass) this value may be increased somehow like $5-10 \mathrm{~cm}$. But it can be said that the height cannot be changed by changing the method. As a matter of fact, the last studies are focused on the improvement of the mothod rather than inventing a new method. In this respect, the MAD method for example may be the method that use minimum power consumption (Table 10). If we look at Table 11, the MAD method is also the most cost effective one among the others. The reason for it is that instead of using external magnetic field, very accurate magnetic sensors are used to detect the Earth's magnetic field. As seen, the MAD method may be preferred taken into account its power consumption, accuracy, portability and cost. However, the disadvantage of this method is the use of it to detect only metal covered mines. This method may be used to detect the metal pins of plastic mines by lowering the detection range and increasing sensor sensitivity. It may be understood that only one method cannot be used for an application looking at its cost, power consumption and sensitivity. Every method has advantages and disadvantages. In order not to depend on only one type of sensor, more than one method has to be used for good results in an application.

\section{Conclusions}

As a conclusion, we may offer the MAD and GPR together for academic studies, because the first criteria for us is the transportability and the time of detection. The cost may be a secondary criterion. Especially, the equipment for determining the explosives within the mines is heavy systems and cannot be transported by a single person. The weight of IR, EMI and acoustic-seismic systems are heavier than that of GPR.

An academician who wants to use a MAD system and a GPR system may carry only a magnetic sensor card and a radio frequency receiver. These systems are enough for her/him. If this academician has aslo a wireless communication medium between herself/himself and a decision and storage center, she/he will not need to have an electronic storing device. In addition, the decision center may evaluate the sensor information and can give a reduced number of alarms to that academician. She/he may choose one of the classification algorithms depending upon her/his requirmennts and available computing capabilities.

\section{References}

[1] Frigui, H. and Gader, P. (2009) Detection and Discrimination of Land Mines in Ground-Penetrating Radar Based on Edge Histogram Descriptors and a Possibilistic $\kappa$-Nearest Neighbor Classifier. IEEE Transactions on Fuzzy Systems, 17, 185-199. http://dx.doi.org/10.1109/TFUZZ.2008.2005249

[2] Robledo, L., Carrasco, M. and Mery, D. (2009) A Survey of Land Mine Detection Technology. International Journal of Remote Sensing, 30, 2399-2410. http://dx.doi.org/10.1080/01431160802549435

[3] Muscio, A. and Corticelli, M.A. (2004) Land Mine Detection by Infrared Thermography Reduction of Size and Duration of the Experiments. IEEE Transaction on Geoscience and Remote Sensing, 42, 1955-1964. http://dx.doi.org/10.1109/TGRS.2004.831443

[4] Khalil, A., Hotait, H., Mrad, M. and Rabbani, T. (2006) Experimental Mine Detection Using Acoustic to Seismic Approach. American University of Beirut Faculty of Engineering and Architecture Department of Electrical and Computer Engineering, Beirut.

[5] Akseli, I., Mani, G.N. and Cetinkaya, C. (2008) Non-Destructive Acoustic Defect Detection in Drug Tablets. International Journal of Pharmaceutics, 360, 65-76. http://dx.doi.org/10.1016/j.ijpharm.2008.04.019

[6] Behboodian, A., Scott, W.R. and McClellan, J.H. (1999) Signal Processing of Elastic Surface Waves for Localizing Buried Land Mines. Proceedings of the Conference Record of the Thirty-Third Asilomar Conference on Signals, Systems and Computers, Pacific Grove, 24-27 October 1999, 827-830.

[7] Schröder, C.T. and Scott, W.R. (2000) Three-Dimension FDTD Model to Study the Elastic-Wave Interaction with Buried Land. Proceedings of IEEE International Geoscience and Remote Sensing Symposium, Honolulu, 24-28 July 2000, 26-28.

[8] Zeng, Y.Q. and Liu, Q.H. (2001) Acoustic Detection of Buried Object in 3-D Fluid Saturated Porous Media: Numerical Modeling. IEEE Transactions on Geoscience and Remote Sensing, 39, 1165-1173. http://dx.doi.org/10.1109/36.927434

[9] Chu, P.C., Cornelius, M. and Wegstaff, M. (2005) Effect of Suspended Sediment on Acoustic Detection Using the Navy's CASS-GRAB Model. Proceedings of MTS/IEEE OCEANS, Washington DC, 17-23 September 2005, 1-7.

[10] Brooks, J.W. and Maier, M.V. (1996) Application of System Idendification and Neural Networks to Classification of 
Land Mines. Proceedings of the EUREL International Conference on the Detection of Abandoned Land Mines: A Humanitarian Imperative Seeking a Technical Solution, Edinburgh, 7-9 October 1996, 46-50.

[11] Daniels, D.J., Curtis, P. and Lockwood, O. (2008) Classification of Landmines Using GPR. Proceedings of IEEE Radar Conference, Rome, 26-30 May 2008, 2235-2240. http://dx.doi.org/10.1109/RADAR.2008.4720994

[12] Kolba, M.P. and Jouny, I.I. (2003) Clutter Suppression and Feature Extraction for Land Mine Detection Using Ground Penetrating Radar. Proceedings of the IEEE Conference on Antennas and Propagation Society International Symposium, Columbus, 22-27 June 2003, 203-206.

[13] Macdonald, J., Lockwood, J.R., McFee, J., Altshuler, T., et al. (2003) Alternatives for Landmine Detection. RAND, Pittsburg.

[14] Ground Penetrating Radar. http://members.comu.edu.tr/yalciner/GPR.html

[15] Chan, L.C., Peters, L. and Moffatt, D.L. (1981) Improved Performance of a Subsurface Radar Target Identification System through Antenna Design. IEEE Transactions on Antennas and Propagation, 29, 307-311. http://dx.doi.org/10.1109/TAP.1981.1142580

[16] Langer, K. (1996) A Guide to Sensor Design for Land Mine Detection. Proceedings of the EUREL International Conference on the Detection of Abandoned Land Mines: A Humanitarian Imperative Seeking a Technical Solution, Edinburgh, 7-9 October 1996, 30-32.

[17] Millot, P. and Berges, A. (1996) Ground Based SAR Imaging Tool for the Design of Buried Mine Detector. Proceedings of the EUREL International Conference on the Detection of Abandoned Land Mines: A Humanitarian Imperative Seeking a Technical Solution, Edinburgh, 7-9 October 1996, 157-159.

[18] Chant, I.J. and Rye, A.R. (1996) Overview of Current Radar Land Mine Detection Research at the Defence Science and Technology Organisation, Salisbury, South Australia. Proceedings of the EUREL International Conference on the Detection of Abandoned Land Mines: A Humanitarian Imperative Seeking a Technical Solution, Edinburgh, 7-9 October 1996, 138-142.

[19] Murray, W., Williams, C.J. and Pollock, J.T.A. (1996) A High Resolution Radar for Mine Detection. Proceedings of the EUREL International Conference on the Detection of Abandoned Land Mines: A Humanitarian Imperative Seeking a Technical Solution, Edinburgh, 7-9 October 1996, 143-147.

[20] Cioni, R., Sensani, S., Bettini, G., Miniati, M. and Moschini, M. (1998) A New General Purpose 1300 MHz Radar Sensor Suitable for Detection of Mines. Proceedings of the Second International Conference on the Detection of Abandoned Land Mines, Edinburgh, 12-14 October 1998, 55-59.

[21] Montoya, T.P. and Smith, G.S. (1999) Land Mine Detection Using a Ground-Penetrating Radar Based on Resistively Loaded Vee Dipoles. Transaction on Antennas and Propagation, 47, 1795-1806. http://dx.doi.org/10.1109/8.817655

[22] Chen, C.C., Nag, S., Bunside, W.D., Halman, J.I., Shubert, K.A. and Peters, L. (2000) A Standoff, Focused-Beam Land Mine Radar. IEEE Transaction on Geoscience and Remote Sensing, 38, 507-514. http://dx.doi.org/10.1109/36.823945

[23] Rappaport, C. and El-Shenawee, M. (2000) Modeling GPR Signal Degradation from Random Rough Ground Surface. Proceedings of IEEE International Geoscience and Remote Sensing Symposium, Honolulu, 24-28 July 2000, 31083110.

[24] Kolba, M.P and Jouny, I.I. (2003) Buried Land Mine Detection Using Complex Natural Resonances on GPR Data. Proceedings of IEEE International Geoscience and Remote Sensing Symposium, Toulouse, 21-25 July 2003, 761-763.

[25] Sato, M. (2003) Bistatic GPR System for Landmine Detection Using Optical Electric Field. Proceedings of IEEE Conference on Antennas and Propagation Society International Symposium, Columbus, 22-27 June 2003, 207-210.

[26] Zhang, C.-C., Kong, L.-J. and Zhou, Z.-O. (2004) Research on Fast Synthetic Aperture Imaging Method for Ground Penetrating Radar in Subsurface Object Detection. Proceedings of International Conference on Communications, Circuits and Systems, Chengdu, 27-29 June 2004, 777-779.

[27] Tanaka, R. and Sato, M. (2004) A GPR System Using a Broadband Passive Optical Sensor for Land Mine Detection. Proceedings of the Tenth International Conference on Ground Penetrating Radar, Delft, 21-24 June 2004, 171-174.

[28] Dumanian, A.J. and Rappaport, C.M. (2005) Enhanced Detection and Classification of Buried Mines with an UWB Multistatic GPR. IEEE Transactions on Antennas and Propagation Society International Symposium, 3B, 88-91.

[29] Cho, S.J., Tanaka, R. and Sato, M. (2005) Bistatic GPR by Using an Optical Electric Field Sensor. Proceedings of IEEE International Geoscience and Remote Sensing Symposium, Seoul, 25-29 July 2005, 348-351.

[30] Clark, W., Burns, B., Sherbondy, K., Ralston, J. and Rappaport, C. (2005) Surface Effects on Ground Penetrating Radar Imagery. IEEE Transactions on Antennas and Propagation Society International Symposium, 1A, 404-407.

[31] Merwe, A. and Gupta, I.J. (2000) A Novel Signal Processing Technique for Clutter Reduction in GPR Measurements of Small, Shallow Land Mines. IEEE Transaction on Geoscience and Remote Sensing, 38, 2627-2637. 
http://dx.doi.org/10.1109/36.885209

[32] Perrin, S., Bibaut, A., Duflos, A. and Vanheeghe, P. (2000) Use of Wavelets for Ground-Penetrating Radar Signal Analysis and Multisensor Fusion in the Frame of Landmines Detection. Proceedings of IEEE International Conference on Systems, Man and Cybernetics, Nashville, 8-11 October 2000, 2940-2945.

[33] Ho, K.C. and Gader, P.D. (2002) A Linear Prediction Land Mine Detection Algorithm for Hand Held Ground Penetrating Radar. IEEE Transaction on Geoscience and Remote Sensing, 40, 1374-1384. http://dx.doi.org/10.1109/TGRS.2002.800276

[34] Rhebergen, J.B. and Van Wijk, R. (2004) Model Based Detection and Identification of Land-Mine Signatures in GPR Data. Proceedings of the Tenth International Conference on Ground Penetrating Radar, Delft, 21-24 June 2004, 677680.

[35] Missaoui, O., Frigui, H. and Gader, P. (2011) Land-Mine Detection with Ground-Penetrating Radar Using Multistream Discrete Hidden Markov Models. IEEE Transaction on Geoscience and Remote Sensing, 49, 2080-2099.

[36] Herman, H. (1997) Robotic Subsurface Mapping Using Ground Penetrating Radar. Doctoral Dissertation, The Robotics Institute Carnegie Mellon University, Pittsburgh.

[37] Ege, Y. (2005) Ferromanyetik Malzemelerin Yüzey Manyetik Akı Profilinin Dedeksiyonu Ve Uygulamaları. TC Balıkesir Üniversitesi Fen Bilimleri Enstitüsü Fizik Ana Bilim Dalı, Ocak.

[38] Collins, L., Gao, P. and Tantum, S. (2001) Model-Based Statistical Signal Processing Using Electromagnetic Induction Data for Landmine Detection and Classification. Proceedings of the 11th IEEE Signal Processing Workshop on Statistical Signal Processing, Orchid Country Club, 6-8 August 2001, 162-165.

[39] Scott, W.R. (2007) Broadband Electromagnetic Induction Sensor for Detecting Buried Landmines. Proceedings of IEEE International Geoscience and Remote Sensing Symposium, Barcelona, 23-28 July 2007, 22-25.

[40] Keiswetter, D., Won, I.J., Barrow, B. and Bell, T. (1999) Object Identification Using Multifrequency EMI Data. Proceedings of the Symposium on the Application of Geophysics to Engineering and Environmental Problems at the Annual Meeting of the EEGS, Oakland, 14-18 March 1999, 743-751. http://dx.doi.org/10.4133/1.2922673

[41] Riggs, L.S., Mooney, J.E. and Lawrence, D.E. (2001) Identification of Metallic Mine-Like Objects Using Low Frequency Magnetic Fields. IEEE Transactions on Geoscience and Remote Sensing, 39, 56-66. http://dx.doi.org/10.1109/36.898665

[42] Sower, G.D. and Cave, S.P. (1995) Detection and Identification of Mines from Natural Magnetic and Electromagnetic Resonances. Proceedings of Detection Technologies for Mines and Minelike Targets, Orlando, 17 April 1995, 10151024. http://dx.doi.org/10.1117/12.211301

[43] Nelson, C.V., Huynh, T.B., Writer, T. and Lacko, P.R. (2001) Horizontal Electromagnetic Field Sensor for Detection and Classification of Metal Targets. In: Dubey, A.C., Harvey, J.F. and Broach, J.T., Eds., Detection and Remediation Technologies for Mines and Minelike Targets VI, SPIE—International Society for Optical Engine, Bellingham, 65-74.

[44] Ramachandran, G., Gader, P.D. and Wilson, N. (2010) GRANMA: Gradient Angle Model Algorithm on Wideband EMI Data for Land-Mine Detection. IEEE Transaction on Geoscience and Remote Sensing Letters, 7, 535-539.

[45] Rennie, C., Arendse, B., Inggs, M.R. and Langman, A. (1998) Practical Measurements of Land Mine Simulants Using a SFCW Radar, a Pulse Induction Metal Detector and an Infrared Camera. Proceedings of the Second International Conference on the Detection of Abandoned Land Mines, Edinburgh, 12-14 October 1998, 182-186.

[46] Lundberg, M. (2000) Reduction of Surface Clutter in Infrared Image with Visual-Wavelength Measurements. Proceedings of IEEE International Geoscience and Remote Sensing Symposium, Honolulu, 24-28 July 2000, 2377-2379.

[47] Svensson, L. and Lundberg, M. (2002) Dual-Band Land Mine Detection Using a Bayesian Approach. Proceedings of IEEE International Conference on Acoustics, Speech and Signal Processing (ICASSP), Orlando, 13-17 May 2002, 1297-1300.

[48] Deans, J., Gerhard, J. and Carter, L.J. (2006) Analysis of a Thermal Imaging Method for Landmine Detection, Using Infrared Heating of the Sand Surface. Infrared Physics \& Technology, 48, 202-216. http://dx.doi.org/10.1016/j.infrared.2005.06.003

[49] Miao, X., Azimi-Sadjadi, M.R., Tian, B., Dubey, A.C. and Witherspoon, N.H. (1998) Detection of Mines and Minelike Targets Using Principal Component and Neural-Network Methods. IEEE Transactions on Neural Network, 9, 454-463. http://dx.doi.org/10.1109/72.668887

[50] Lopez, P., Vilarino, D.L., Cabello, D., Sahlı, H. and Balsı, M. (2002) CNN Based 3D Thermal Modeling of the Soil for Antipersonnel Mine Detection. Proceedings of the 7th IEEE International Workshop on Cellular Neural Networks and Their Applications, Frankfurt, 22-24 July 2002, 307-314.

[51] Frost, R., Appleby, R., Price, S. and Nivelle, F. (1996) The Detection of Mines Using RF/Millimetric Radiometry. Proceedings of EUREL International Conference on the Detection of Abandoned Land Mines: A Humanitarian Imper- 
ative Seeking a Technical Solution, Edinburgh, 7-9 October 1996, 92-96.

[52] Maathius, B. and Van Genderen, J. (2004) A Review of Satellite and Airborne Sensors for Remote Sensing Based Detection of Minefields and Landmines. International Journal of Remote Sensing, 25, 5201-5245. http://dx.doi.org/10.1080/01431160412331270803

[53] Blauch, A.J., Schiano, J.L. and Ginsberg, M.D. (1999) Landmine Detection Using Feedback NQR. Proceedings of Detection and Remediation Technologies for Mines and Minelike Targets IV Conference, Orlando, 5-9 April 1999.

[54] Ostafin, M. and Nogaj, B. (2007) ${ }^{14} \mathrm{~N}-\mathrm{NQR}$ Based Device for Detection of Explosives in Landmines. Measurement, 40, 43-54. http://dx.doi.org/10.1016/j.measurement.2006.04.003

[55] McFee, J.E., Faust, A.A., Andrews, H.R., Kovaltchouk, V., Clifford, E.T. and Ing, H. (2009) A Comparison of Fast Inorganic Scintillators for Thermal Neutron Analysis Landmine Detection. IEEE Transactions on Nuclear Science, 56, 1584-1592.

[56] Jakobsson, A., Mossberg, M., Rowe, M.D. and Smith, J.A.S. (2006) Exploiting Temperature Dependency in the Detection of NQR Signal. IEEE Transactions on Signal Processing, 54, 1610-1616. http://dx.doi.org/10.1109/TSP.2006.871969

[57] Deas, R.M. and Belvoir, F. (2004) Landmine Detection by Nuclear Quadrupole Resonance (NQR). www.dtic.mil/cgi-bin/GetTRDoc?AD

[58] Godzins, L., Macdonald, J. and Lookwood, J.R. (2003) X-Ray Backscatter. In: Macdonald, J. and Lookwood, J.R., Eds., Alternatives for Landmine Detection, RAND Publication, 191-204.

[59] Clifford, E.T.H., McFee, J.E., Ing, H., Andrews, H.R., Tennant, D., Harper, E. and Faust, A.A. (2007) A Militarily Fielded Thermal Neutron Activation Sensor for Landmine Detection. Nuclear Instruments and Methods in Physics Research, 579, 418-425. http://dx.doi.org/10.1016/j.nima.2007.04.091

[60] Miri-Hakimabad, H., Vejdani-Noghreiyan, A. and Panjeh, H. (2007) The Safety of a Landmine Detection System Using Graphite and Polyethylene Moderator. International Journal of Radiation Research, 5, 137-142.

[61] McFee, J.E. and Faust, A.A. (2003) Defence R\&D Canada Research on Nuclear Methods of Landmine Detection. In: Broach, J.T., Harmon, R.S. and Holloway, J.H., Eds., Detection and Remediation Technologies for Mines and Minelike Targets VIII, SPIE, Bellingham, 1-12.

[62] Sood, D.D., Rosengard, U. and Trkov, A. (2003) Development of Nuclear Technique for the Detection of Landmines. In: Broach, J.T., Harmon, R.S. and Holloway, J.H., Eds., Detection and Remediation Technologies for Mines and Minelike Targets VIII, SPIE, Bellingham, 13-24.

[63] Vourvopoulos, G., Womble, P.C. and Paschal, J. (2000) PELAN: A Pulsed Neutron Portable Probe for UXO and Landmine Identification. Proceedings of Penetrating Radiation Systems and Applications II, San Diego, 30 July 2000, 142-149. http://dx.doi.org/10.1117/12.410556

[64] Miri-Hakimabad, H., Panjeh, H. and Vejdaninoghreiyan, A. (2008) Experimental Optimization of a Landmine Detection Facility Using PGNAA Method. Nuclear Science and Techniques, 19, 109-112. http://dx.doi.org/10.1016/S1001-8042(08)60033-0

[65] Im, H.-J., Cho, H.-J., Song, B.C., Park, Y.J., Chung, Y.-S. and Kim, W.-H. (2006) Analytical Capability of an Explosives Detection by a Prompt Gamma-Ray Neutron Activation Analysis. Nuclear Instruments and Methods in Physics, 566, 442-447.

[66] Csikai, J., Doczi, R. and Kiraly, B. (2004) Investigations on Landmine Detection by Neutron-Based Techniques. Applied Radiation and Isotopes, 61, 11-20. http://dx.doi.org/10.1016/j.apradiso.2004.02.011

[67] Bom, V., Ali, M.A. and Van Eijk, C.W.E. (2006) Land Mine Detection with Neutron Back Scattering Imaging Using a Neutron Generator. IEEE Transactions on Nuclear Science, 53, 356-360. http://dx.doi.org/10.1109/TNS.2006.869841

[68] Bom, V.R., Datema, C.P. and Van Eijk, C.W.E. (2003) DUNBLAD, the Delft University Neutron Backscatter Land-Mine Detector. Proceedings of Detection and Remediation Technologies for Mines and Minelike Targets VIII, Orlando, 21 April 2003, 25-33.

[69] Bom, V.R., Datema, C.P. and Van Eijk, C.W.E. (2004) The Status of the Delft University Neutron Backscatter Landmine Detector (DUNBLAD). Applied Radiation and Isotopes, 61, 21-25. http://dx.doi.org/10.1016/j.apradiso.2004.02.012

[70] Vanier, P.E., Forman, L., Hunter, S.J., Haris, E.J. and Smith, G.C. (2004) Thermal Neutron Backscatter Imaging. Proceedings of IEEE Nuclear Science Symposium Conference Record, Rome, 16-22 October 2004, 201-205. http://dx.doi.org/10.1109/NSSMIC.2004.1462181

[71] Bom, V.R., Datema, C.P. and Van Eijk, C.W.E. (2003) DUNBLAD, the Delft University Neutron Backscatter Land-Mine Detector, a Status Report. Application of Accelerators in Research and Industry, 680, 935-938. 
http://dx.doi.org/10.1063/1.1619862

[72] Sood, D.D., Rosengard, U. and Trkov, A. (2003) Development of Nuclear Technique for the Detection of Landmines. In: Broach, J.T., Harmon, R.S. and Holloway, J.H., Eds., Detection and Remediation Technologies for Mines and Minelike Targets VIII, SPIE, Bellingham, 13-24.

[73] Takahashi, Y., Misawa, T., Masuda, K., Yoshikawa, K., et al. (2010) Development of Landmine Detection System Based on the Measurement of Radiation from Landmines. Applied Radiation and Isotopes, 68, 2327-2334.

[74] Faust, A.A., Rothschild, R.E., Leblanc, P. and McFee, J.E. (2009) Development of a Coded Aperture X-Ray Backscatter Imager for Explosive Device Detection. IEEE Transactions on Nuclear Science, 56, 299-307. http://dx.doi.org/10.1109/TNS.2008.2009537

[75] Jacobs, A.M., Dugan, E.T., Su, Z. and Wells, C.J. (1998) Detection/Identification of Land Mines by Lateral Migration Radiography. Proceedings of the Second International Conference on the Detection of Abandoned Land Mines, Edinburgh, 12-14 October 1998, 152-156.

[76] Yuk, S., Kim, K.H. and Yi, Y. (2006) Detection of Buried Landmine with X-Ray Backscatter Technique. Nuclear Instruments and Methods in Physics, 568, 388-392. http://dx.doi.org/10.1016/j.nima.2006.07.022

[77] Faust, A.A. (2002) Detection of Explosive Devices Using X-Ray Backscatter Radiation. Proceedings of the Penetrating Radiation Systems and Applications IV, Seattle, 07 July 2002, 17-28.

[78] Keshavmurthy, S.P., Dugan, E.T., Wehlburg, J.C. and Jacobs, A.M. (1996) Analytical Studies of a Backscatter X-Ray Imaging Landmine Detection System. Proceedings of the Detection and Remediation Technologies for Mines and Minelike Targets, Orlando, 8 April 1996, 512-523.

[79] Lockwood, G., Shope, S., Bishop, L., Selph, M. and Jojola, J. (1997) Mine Detection Using Backscattered X-Ray Imaging of Antitank and Antipersonnel Mines. Proceedings of the Detection and Remediation Technologies for Mines and Minelike Targets II, Orlando, 21 April 1997, 408-417.

[80] Shope, S., Lockwood, G., Bishop, L., Selph, M., Jojola, J., Wavrik, R., Turman, B. and Wehlburg, J. (1997) Mobile, Scanning X-Ray Source for Mine Detection Using Backscattered X-Rays. Proceedings of the Detection and Remediation Technologies for Mines and Minelike Targets II, Orlando, 21 April 1997, 400-407.

[81] Lockwood, G.J., Shope, S.L., Wehlburg, J.C., Selph, M.M., Jojola, J.M., Turman, B.N. and Jacobs, J.A. (1998) Field Tests of X-Ray Backscatter Mine Detection. Proceedings of the Second International Conference on the Detection of Abandoned Land Mines, Edinburgh, 12-14 October 1998, 160-163. http://dx.doi.org/10.1049/cp:19980711

[82] Wehlburg, J., Shope, S., Lockwood, G., Selph, M., Jojola, J., Jacobs, J. and Turman, B. (1998) Field Trials of Mobile X-Ray Source for Mine Detection Using Backscattered X-Rays. Proceedings of the Detection and Remediation Technologies for Mines and Minelike Targets III, Orlando, 13 April 1998, 888-892.

[83] Wehlburg, J.C., Jacobs, J., Shope, S.L., Lockwood, G.J. and Selph, M.M. (1999) Landmine Detection Using Backscattered X-Ray Radiography. Proceedings of the Penetrating Radiation Systems and Applications, Denver, 18 July 1999, 149-154. http://dx.doi.org/10.1117/12.363675

[84] Lenz, J.E. (1990) A Review of Magnetic Sensors. Proceedings of the IEEE, 78, 973-989.

[85] Clem, T.R. (2002) Sensor Technologies for Hunting Buried Sea Mines. OCEANS’02 MTS/IEEE, 1, $452-460$.

[86] El Tobelyl, T. and Salem, A. (2005) Position Detection of Unexploded Ordnance from Airborne Magnetic Anomaly Data Using 3-D Self Organized Feature Map. Proceedings of the 5th IEEE International Symposium on Signal Processing and Information Technology, Athens, 21-21 December 2005, 322-327.

[87] Sheinker, A., Salomonski, N., Ginzburg, B., Frumkis, L. and Kaplan, B.Z. (2005) Aeromagnetic Search Using Genetic Algorithm. Proceedings of Progress in Electromagnetics Research Symposium, Hangzhou, 22-26 August 2005, 492-495.

[88] Şensoy, M.G. (2010) Manyetik Karakteristeki Malzemelerin Manyetik Alanda Oluşturdukları Anomali İle Belirlenmesi Ve Oluşan Anomaliye Göre Manyetik Malzemenin Karakterizasyonu. Yüksek Lisans Tezi, Balıkesir Üniversitesi Fen Bilimleri Enstitüsü, Temmuz.

[89] Vyhnanek, J., Janosek, M. and Ripka, P. (2011) AMR Gradiometer for Mine Detection and Sensing. Procedia Engineering, 25, 362-366.

[90] Vyhnanek, J., Janosek, M. and Ripka, P. (2012) AMR Gradiometer for Mine Detection. Sensors and Actuators A: Physical, 186, 100-104. http://dx.doi.org/10.1016/j.sna.2012.03.007

[91] Chen, Q., Yuan, Q.W. and Sawaya, K. (2003) MoM Analysis of Patch Antenna Array Using Fast Algorithm for Solving Matrix Equation. Proceedings of IEEE International Symposium on the Antennas and Propagation Society, Columbus, 22-27 June 2003, 807-810.

[92] Vidal, C.F.V.P. and Resende, U.C. (2011) Solution Ofintegral Equation in Scattering Analysis of Conducting Bodies of Revolution by MoM with First Type Elliptic İntegrals. Proceedings of the 4th International Conference on Computational Methods for Coupled Problems in Science and Engineering IV, Kos, 20-22 June 2011, 1232-1238. 
[93] Medgyesi-Mitschang, L., Putnam, J. and Gedera, M. (1994) Generalized Method of Moments for Three-Dimensional Penetrable Scatters. Journal of the Optical Society of America A: Optics, Image Science and Vision, 11, 1383-1398. http://dx.doi.org/10.1364/JOSAA.11.001383

[94] Mautz, J.R. and Harrington, R.F. (1980) An Improved E-Field Solution for a Conducting Body of Revolution. Technical Report TR-80-1, NTIS Issue Number 8103.

[95] Ylä-Oijala, P. and Taskinen, M. (2005) Well-Conditioned Müller Formulation for Electromagnetic Scattering by Dielectric Objects. IEEE Transactions on Antennas and Propagation, 53, 3316-3323. http://dx.doi.org/10.1109/TAP.2005.856313

[96] Kishk, A.A. and Shafai, L. (1989) Improvement of the Numerical Solution of Dielectric Bodies with High Permittivity. IEEE Antennas and Propagation, 37, 1486-1490. http://dx.doi.org/10.1109/8.43570

[97] Kolundzija, B.M. (1999) Electromagnetic Modeling of Composite Metallic and Dielectric Structures. IEEE Transactions on Microwave Theory and Techniques, 47, 1021-1032. http://dx.doi.org/10.1109/22.775434

[98] Kim, D., Chen, Q. and Sawaya, K. (2001) Numerical Analysis for Broadband Phased Array of Log-Periodic Dipole Array Antenna Elements. Proceedings of IEEE Antennas and Propagation Society International Symposium, Boston, 8-13 July 2001, 824-827.

[99] Peterson, A.F. and Mittra, R. (1986) Convergence of the Conjugate Gradient Method When Applied to Matrix Equations Representing Electromagnetic Scattering Problems. IEEE Transactions on Antennas and Propagation, 34, 14471454. http://dx.doi.org/10.1109/TAP.1986.1143780

[100] Hestenes, M.R. and Stiefel, E. (1952) Methods of Conjugate Gadients for Solving Linear Systems. Journal of Research of the National Bureau of Standards, 49, 409-436. http://dx.doi.org/10.6028/jres.049.044

[101] Tunc, C.A., Akleman, F., Erturk, V.B., et al. (2006) Fast İntegral Equation Solutions: Application to Mixed Path Terrain Profiles and Comparisons with Parabolic Equation Method. Springer Proceedings in Physics, 104, 55-63.

[102] Sevgi, L. and Felsen, L.B. (1998) A New Algorithm for Ground Wave Propagation Based on a Hybrid Ray-Model Approach. International Journal of Numerical Modeling, 11, 87-103. http://dx.doi.org/10.1002/(SICI)1099-1204(199803/04)11:2<87::AID-JNM291>3.0.CO;2-6

[103] Levy, M. (2000) Parabolic Equation Methods for Electromagnetic Wave Propagation. IEE, Institution of Electrical Engineers.

[104] Leontovich, M.A. and Fock, V.A. (1946) Solution of the Problem of Propagation of Electromagnetic Waves along the Earth's Surface by Method of Parabolic Equations. Journal of Physics-USSR, 10, 13-23.

[105] Tappert, F.D. (1977) The Parabolic Approximation Method. In: Keller, J.B. and Papadakis, J.S., Eds., Chapter 5: Wave Propagation and Underwater Acoustics, Springer-Verlag, New York, 224-287. http://dx.doi.org/10.1007/3-540-08527-0_5

[106] Di Napoli, F.R. and Daeavenport, R.L. (1977) Numerical Methods of Underwater Acoustic Propagation. Numerical Methods of Underwater Acoustic Propagation. In: De Santo, J.A., Ed., Ocean Acoustics, Springer-Verlag, New York.

[107] Kron, G. (1944) Equivalent Circuit of the Field Equations of Maxwell-I. Proceedings of the IRE, 32, 289-299.

[108] Whinnery, J.R. and Ramo, S. (1944) A New Approach to the Solution of High Frequency Field Problems. Proceedings of the IRE, 32, 284-288.

[109] Vine, J. (1966) Impedance Networks. In: Vitkovitch, D., Ed., Chapter 7: Field Analysis: Experimental and Computational Methods, D. Van Nostrand Company.

[110] Johns, P.B. and Beurle, R.L. (1971) Numerical Solution of 2-Dimensional Scattering Problems Using a Transmission-Line Matrix. Proceedings of IEE, 118, 1203-1208.

[111] Arlett, P.L., Bahrani, A.K. and Zienkiewicz, O.C. (1968) Application of Finite Elements to the Solution of Helmholtz's Equation. Proceedings of IEE, 115, 1762-1766.

[112] Hornsby, J.S. and Gopinath, A. (1969) Numerical Analysis of a Dielectric Loaded Waveguide with a Microstrip Line-Finite-Difference Methods. IEEE Transactions on Microwave Theory and Techniques, 17, 684-690.

[113] Ahmed, S. and Dally, P. (1969) Finite-Element Methods for Inhomogeneous Waveguides. Proceedings of IEE, 116, 1661-1664.

[114] Masterman, P.H. and Clarricoats, P.J.B. (1971) Computer Field-Matching Solution of Waveguide Transverse Discontinuities. Proceedings of IEE, 118, 51-63.

[115] Kane, S.Y. (1966) Numerical Solution of Initial Boundary Value Problems Involving Maxwell’s Equations in Isotropic Media. IEEE Transaction on Antennas and Propagation, 14, 302-307. http://dx.doi.org/10.1109/TAP.1966.1138693

[116] Özyalçin, M.O. and Sevgi, L. (1998) Comparisons of FDTD and TLM Methods in EMC-Shielding Effectiveness Analysis. Proceedings of the Eighth Biennial IEEE Conference on Electromagnetic Field Computation, Tucson, 1-3 
June 1998.

[117] Gürel, L. and Oğuz, U. (2000) Three-Dimensional FDTD Modeling of a Ground-Penetrating Radar. IEEE Transactions on Geoscience and Remote Sensing, 38, 1513-1521. http://dx.doi.org/10.1109/36.851951

[118] Nazlibilek, S., Ege, Y., Kalender, O., Sensoy, M.G., Karacor, D. and Sazli, M.H. (2012) Identification of Materials with Magnetic Characteristics by Neural Networks. Measurement, 45, 734-744. http://dx.doi.org/10.1016/j.measurement.2011.12.017

[119] Nazlibilek, S., Kalender, O. and Ege, Y. (2011) Mine Identification and Classification by Mobile Sensor Network Using Magnetic Anomaly. IEEE Transactions on Instrumentation and Measurement, 60, 1028-1036. http://dx.doi.org/10.1109/TIM.2010.2060220

[120] Kuttler, J.R. and Dockery, G.D. (1991) Theoretical Description of the Parabolic Approximation/Fourier Split-Step Method of Representing Electromagnetic Propagation in the Troposphere. Radio Science, 26, 381-393. http://dx.doi.org/10.1029/91RS00109 
Scientific Research Publishing (SCIRP) is one of the largest Open Access journal publishers. It is currently publishing more than 200 open access, online, peer-reviewed journals covering a wide range of academic disciplines. SCIRP serves the worldwide academic communities and contributes to the progress and application of science with its publication.

Other selected journals from SCIRP are listed as below. Submit your manuscript to us via either submit@scirp.org or Online Submission Portal.
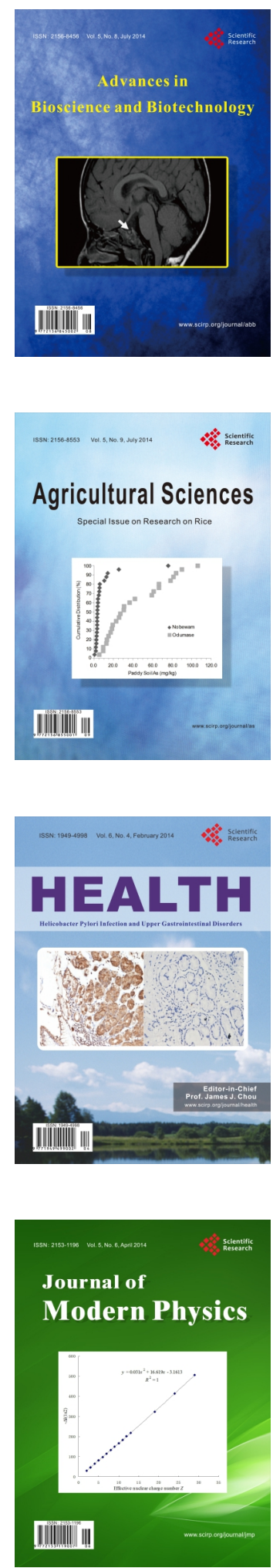
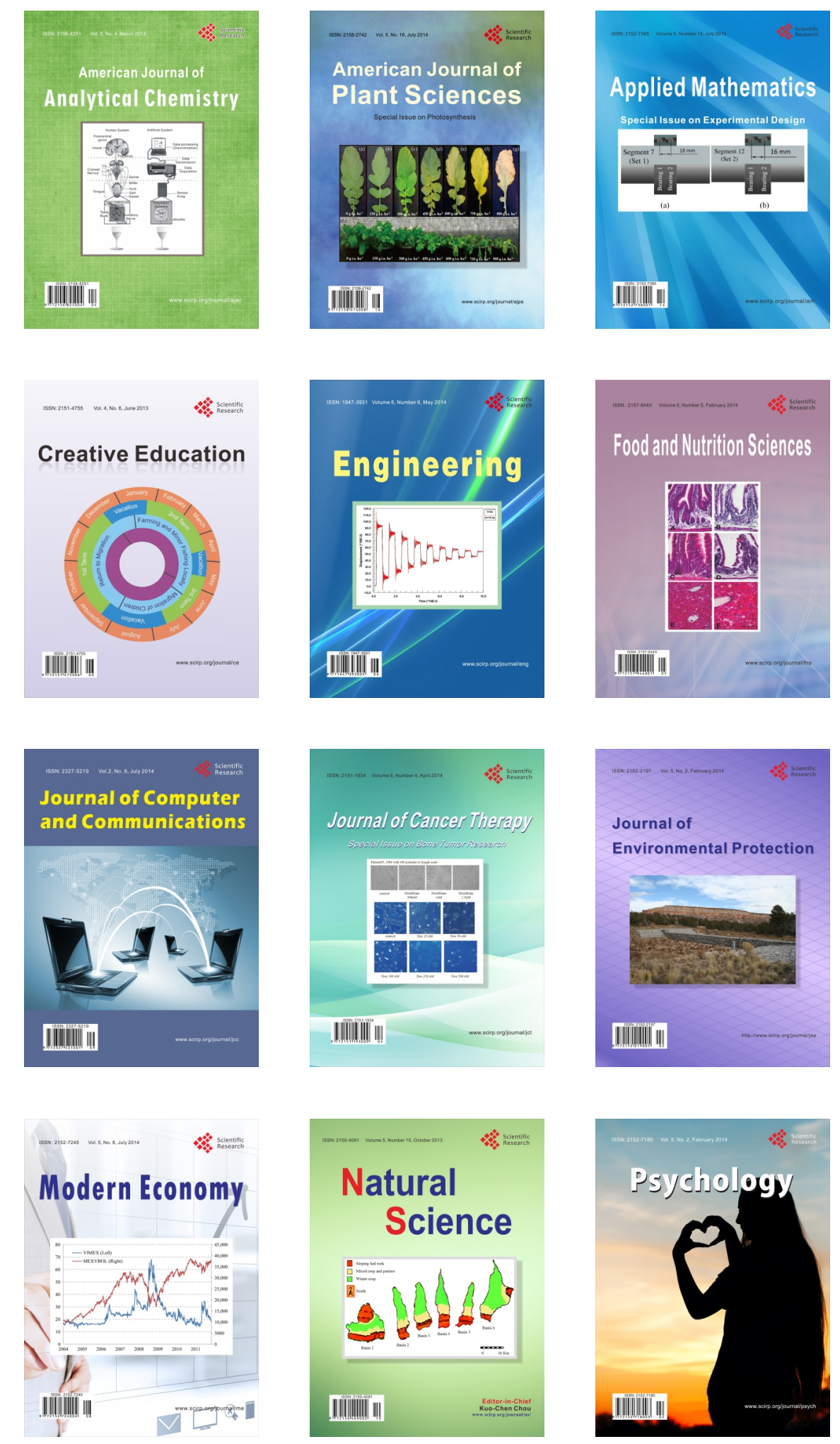